\title{
Water quality in recirculating aquaculture system using woodchip denitrification and slow sand filtration
}

\author{
Petra Lindholm-Lehto ${ }^{1}$ (D) - Jani Pulkkinen ${ }^{1} \cdot$ Tapio Kiuru $^{1} \cdot$ Juha Koskela $^{1} \cdot$ Jouni Vielma $^{1}$
}

Received: 10 July 2019 / Accepted: 21 February 2020 / Published online: 10 March 2020

(C) The Author(s) 2020

\begin{abstract}
In recirculating aquaculture system (RAS), ammonium excreted by the fish is typically transformed to less toxic nitrate by microbial activity in bioreactors. However, nitrate-nitrogen load can be harmful for the receiving water body when released from the RAS facility. A new type of water treatment system for a RAS was designed, including a passive woodchip denitrification followed by a sand filtration introduced into a side-loop of an experimental RAS, rearing rainbow trout (Oncorhynchus mykiss). In the process, woodchips acted as a carbon source for the denitrification, aiming at a simultaneous nitrogen removal and reduction of water consumption while sand filtration was used to remove organic matter and recondition the circulating water. A variety of chemical analyses and toxicological tests were performed to study the suitability of the process and to ensure the absence of harmful or toxic substances in the system. The results did not show increased toxicity, and no increased mortality was reported for the raised species. After the start-up of the system, the concentrations of fatty acids (e.g., hexadecanoic acid <LOD$1.21 \mathrm{mg} \mathrm{L}^{-1}$ ) and heavy metals (e.g., $\mathrm{Cd}<\mathrm{LOD}-0.45 \mu \mathrm{g} \mathrm{L}^{-1}, \mathrm{~Pb}<\mathrm{LOD}-14 \mu \mathrm{g} \mathrm{L}^{-1}$ ) remained at very low levels and below those of known toxic effects. In the beginning of the experiment, good denitrification efficiency was achieved, but it declined after 1 month, showing the need for improved stability and dimensioning of the application.
\end{abstract}

Keywords Gas chromatography (GC) · Heavy metals · Inductively coupled plasma optical emission spectrometry (ICP-OES) · Inductively coupled plasma mass chromatography (ICP-MS) · Ion chromatography (IC) - Rainbow trout · Recirculating aquaculture system (RAS)

\section{Introduction}

Land-based intensive recirculating aquaculture system (RAS) enables reduction in water consumption and nutrient discharge (Dalsgaard et al. 2013), but it often leads to the generation of highly concentrated waste streams, high in solids and nutrients. In a conventional RAS, the external water requirement is adjusted, based on the maximum acceptable concentration of nitrate in the system (Schuster and Stelz 1998;

Responsible editor: Philippe Garrigues

Electronic supplementary material The online version of this article (https://doi.org/10.1007/s11356-020-08196-3) contains supplementary material, which is available to authorized users.

Petra Lindholm-Lehto

petra.lindholm-lehto@luke.fi

1 Aquatic Production Systems, Natural Resources Institute Finland (Luke), Survontie 9A, FI-40500 Jyväskylä, Finland
Martins et al. 2010). Typically, about $5 \%$ of the system water is replaced daily with clean water to prevent accumulation of nitrate and dissolved organic solids (Masser et al. 1999; Colt 2006; van Rijn et al. 2006). The amount of nitrate must be reduced to avoid toxic effects for the raised species and to further reduce the inlet water consumption. High nitrate concentrations (> $100 \mathrm{mg} \mathrm{L}^{-1} \mathrm{NO}_{3}-\mathrm{N}$, Chen et al. 2002) can be harmful for the raised species but also potentially lead to eutrophication of the receiving waters if released untreated. Eutrophication of water bodies is globally a severe problem (Sharrer et al. 2016). It has been estimated that annual economic losses due to eutrophication is over 2.2 billion US dollars (Dodds et al. 2009).

Denitrification is the process of transforming oxidized nitrogen compounds (nitrite, $\mathrm{NO}_{2}{ }^{-}$and nitrate, $\mathrm{NO}_{3}{ }^{-}$) to reduced elemental gaseous nitrogen $\left(\mathrm{N}_{2}\right)$ via facultative anaerobic microorganisms (van Rijn et al. 2006). In heterotrophic denitrification, bacteria are able to convert nitrate to nitrogen gas under anaerobic conditions, using nitrate as an electron acceptor, a carbon source as the electron donor, and for 
growth, catalyzed by specific enzymes (Seitzinger et al. 2006; Rivett et al. 2008; Tallec et al. 2008). Denitrification rate depends on several factors, such as temperature, hydraulic retention time (HRT), and microbiology (Christianson et al. 2012). Nitrate removal rate typically increases with increasing temperature, but moderate rates can be achieved even at $1-5{ }^{\circ} \mathrm{C}$ (Schipper et al. 2010b). In systems with high nitrogen loadings, rates of nitrogen removal can be limited by temperature or the availability of carbon (Gibert et al. 2008; Schipper et al. 2010b; Warneke et al. 2011). Denitrification increases the alkalinity in the system and returns some of the inorganic carbon lost during nitrification back into the system.

Typically, nitrifying bioreactors are used for the removal of ammonia, transforming it to nitrite and, further to less toxic nitrate to aquatic species. In most recirculating systems, nitrifying filters have been incorporated, but denitrifying filters are still under development. Denitrification has been applied mainly to remove toxic nitrogen compounds and to prevent them from harming the raised species. Additionally, denitrification can be applied to remove nitrate-nitrogen due to increased environmental regulations related to effluent discharge, elimination of organic carbon, and sulfide from the circulating water (van Rijn et al. 2006; von Ahnen et al. 2018). According to some evaluations (Eding et al. 2006), denitrification added to a conventional RAS process decreases the actual production costs per $\mathrm{kg}$ of fish due to alkalinity production by denitrification, decreasing the need for external alkalinity, even though it has somewhat higher requirements for electricity and oxygen.

Denitrification is widely used in drinking water (Aslan and Cakici 2007) and wastewater treatment applications (Fernández-Nava et al. 2008). In wastewater treatment with denitrification, commercial electron and carbon donors are often used, such as carbohydrates and organic alcohols. Moreover, agricultural and wood by-products have been tested as a reactor media and denitrification carbon source, such as wheat straw (Aslan and Turkman 2003), and woodchips (Saliling et al. 2007), but some of them offer only limited availability of dissolved organic carbon for the denitrification, leading to low nitrate removal (Robertson et al. 2005). Among natural organic materials, woodchips are the most commonly used in field-scale denitrification due to their good availability, low cost, and good hydraulic permeability (Schipper et al. 2010a). As the water flows through the woodchip bioreactor, oxygen is removed due to bacterial metabolism leading to anoxic environment (Greenan et al. 2006; Warneke et al. 2011). Wood has a high $\mathrm{C} / \mathrm{N}$ ratio and it can act as source of labile carbon, suitable for long-term denitrification (Gibert et al. 2008; Schipper et al. 2010b). In recent years, woodchipbased denitrification has been applied in RAS in the USA (Lepine et al. 2018) and in Denmark (von Ahnen et al. 2018, 2019), including full-scale applications.
Denitrification in a woodchip bioreactor can range from 2 to $22 \mathrm{~g}$ of removed $\mathrm{N} \mathrm{m}^{-3} \mathrm{~d}^{-1}$, depending on the type of wastewater (Schipper et al. 2010b; Christianson et al. 2012). Greenan et al. (2006) reported that woodchip bioreactors achieved denitrification of 19-26 $\mathrm{g} \mathrm{N} \mathrm{m}^{-3} \mathrm{~d}^{-1}$ with 10 $80 \mathrm{mg} \mathrm{L}^{-1} \mathrm{NO}_{3}-\mathrm{N}$ load. Saliling et al. (2007) achieved denitrification rates of $1360 \mathrm{~g} \mathrm{~N} \mathrm{~m}^{-3} \mathrm{~d}^{-1}$ for woodchips with $200 \mathrm{mg} \mathrm{NO}_{3}-\mathrm{N} \mathrm{L}^{-}$but used methanol addition to ensure full availability of dissolved carbon. Saliling et al. (2007) also showed that woodchips are suitable as a reactor media but estimated that their expected life span was only up to 1 year. Later, a life span of over 10 years has been estimated for similar purposes (Sharrer et al. 2016), while 5-15 years has also been reported due to slow degradation of woodchips under anoxic conditions (Schipper et al. 2010a).

Woodchips can contain various compounds toxic to raised species, including salmonids, such as resin acids (Oikari et al. 1983), retene (7-isopropyl-1-methylphenantrene) (Billiard et al. 1999; Oikari et al. 2002), or heavy metals, depending on the wood species (Świetlik et al. 2012) and its place of growth. Long-chained unsaturated fatty acids, such as oleic, linoleic, linolenic, and palmitoleic can contribute to the toxicity of these waste streams (Leach and Thakore 1978). Additionally, organic compounds and nutrients can leach during the start-up of the process, which is one of the downsides of woodchip denitrification bioreactors (Cameron and Schipper 2010; Healy et al. 2012).

Infiltration of water through sand-containing soil removes dissolved and particulate matter from water and improves its quality. In the formation of natural groundwater, retention of dissolved organic compounds into the soil proceeds via physical and chemical retention mechanisms and biological degradation ( $\mathrm{Wu}$ et al. 2010; Lindroos et al. 2016). Similarly, infiltration of water through the sandy soil layer is also used in artificial recharge of groundwater (ARG, Peters 1998) and widely used in the production of drinking water in the Nordic countries (Kolehmainen et al. 2008). In the application of this study, the circulating water returning from the woodchip bioreactor and denitrification was led into a sand filter to recondition the discharge water before returning it back into circulation.

Denitrification in RAS is still a less studied process, especially without a commercial carbon source and, excluding only a few studies (von Ahnen et al. 2018), often limited to small-scale trials. The aim of this study was to utilize passive water treatment application for denitrification and to reduce water consumption in RAS rearing rainbow trout Oncorhynchus mykiss. Additionally, the goal was to identify and quantify organic and inorganic compounds released during the start-up of the system and later during the experiment, to confirm the suitability of the application for water treatment in a RAS and for the raised species. 


\section{Materials and methods}

\section{Experimental setup}

Two different-sized passive water treatment systems were connected to randomly selected, individual RAS using randomly allocated duplicate systems per treatment. Additionally, control systems without a passive treatment side-loop were operated accordingly (Table 1). Excluding the side-loop, the regular water treatment units were similar in all RASs. A more detailed description of the experimental RAS facility is reported by Pulkkinen et al. (2018). In brief, each RAS consisted of a 500-L fish tank and a separate water treatment system with total water volume of $1000 \mathrm{~L}$. Solids removal system included a waste feed collector and swirl separator. In the present trial, an up-flow fixed-bed bioreactor $(150 \mathrm{~L})$ followed by a moving-bed bioreactor $(150 \mathrm{~L})$ were used, filled with $70 \mathrm{~L}$ of RK BioElements heavy $\left(750 \mathrm{~m}^{2} \mathrm{~m}^{-3}\right)$ carrier material, stabilized to full maturity prior to the start of the trial. Dissolved carbon dioxide was removed from the water by a forced-ventilated cascade aeration column, with Bio-Blok 200 (EXPO-NET Danmark A/S, Denmark) filter media.

A side-loop of passive water treatment included a woodchip bioreactor filled with 57-L (small side-loop) or 91-L (large side-loop) unbarked silver birch (Betula pendula) woodchips $\left(<5 \mathrm{~cm}\right.$, effective porosity $\left.\mathrm{n}_{\mathrm{e}} 0.65\right)$, aiming for 95\% denitrification efficiency $\left(1.4 \mathrm{~g} \mathrm{NO}_{3}-\mathrm{N} \mathrm{d}^{-1}\right.$ or $2.3 \mathrm{~g}$ $\mathrm{NO}_{3}-\mathrm{N} \mathrm{d}^{-1}$ ), with a 1.5-day EBCT (empty bed contact time, hydraulic retention time of the reactor without the woodchips). A sand filter with an effective porosity $\left(\mathrm{n}_{\mathrm{e}}\right)$ of 0.35 was packed with $31 \mathrm{~cm}$ ( $90 \mathrm{~L}$, small side-loop) or $50 \mathrm{~cm}$ of sand (140 L, large side-loop) with $80 \%$ saturation zone and an EBCT of 3.5 days before returning the water back to the pump sump. The amount of water led to the side-loop was measured and adjusted by a peristaltic pump. The water flowed passively first through the woodchip bed and then through the sand filter, exiting the reactor via an overflow (Fig. 1). Denitrification efficiencies were calculated after 3, 6 , and 9 weeks of experiment by measuring $\mathrm{NO}_{3}-\mathrm{N}$ by a spectrophotometer (Procedure 8038 Nessler, LCK340, DS 3900, Hach, Loveland, USA).

Surface water from an oligotrophic Lake Peurunka (area of $694 \mathrm{ha}, 59,613 \mathrm{~m}^{3}$ ) was used as the clean replacement water at the relative water renewal rate of $25 \mathrm{~L} \mathrm{day}^{-1}\left(250 \mathrm{~L} \mathrm{~kg}^{-1}\right.$ feed $\mathrm{d}^{-1}$, small side-loop), $10 \mathrm{~L} \mathrm{day}^{-1}\left(100 \mathrm{~L} \mathrm{~kg}^{-1}\right.$ feed d $\mathrm{d}^{-1}$, large side-loop), and $50 \mathrm{~L} \mathrm{day}^{-1}\left(500 \mathrm{~L} \mathrm{~kg}^{-1}\right.$ feed d $\mathrm{d}^{-1}$ ) for the control systems.

Oxygen levels in the fish tanks were kept at 7.6-8.2 $\mathrm{mg} \mathrm{L}^{-1}$ by injecting oxygen into the pump sumps. Water temperature was maintained at $15.5 \pm 0.7^{\circ} \mathrm{C}$ and the $\mathrm{pH}$ at 7.2 in the pump sump throughout the experiment. Adjustment of $\mathrm{pH}$ was performed by adding $10 \% \mathrm{NaOH}$ (aq) solution. All measured values were monitored constantly and adjusted when required. Total suspended solids, total organic carbon and turbidity (spectro::lyser, s::can, Vienna, Austria), $\mathrm{O}_{2}$ (OxyGuard, Farum, Denmark), $\mathrm{CO}_{2}$ (Franatech, Lüneburg, Germany), and $\mathrm{pH}$ (ProMinent, Heidelberg, Germany) were measured online every $6 \mathrm{~min}$ from the fish tank. Additionally, total ammonia, nitrite, and nitrate nitrogen were monitored weekly by quick laboratory tests (Procedure 8038 Nessler, LCK340, LCK341, UN3316 9 II, Supplementary Table S1), alkalinity by a standard titration method (ISO 9963-1:1994, TitraLab AT1000, Hach, Loveland, USA), and turbidity with a Hach 2100Q Turbidimeter, USA. Circulating water flow rate was set to $0.2 \mathrm{~L} \mathrm{~s}^{-1}$.

\section{Fish and feeding}

The experiment was conducted in the summer of 2018 for 10 weeks. In the beginning, there were 300 fish in each tank, weighing on average $13.2 \pm 0.2 \mathrm{~g}\left(8.0 \mathrm{~kg} \mathrm{~m}^{-3}\right)$ and, increasing

Table 1 Operational design of RAS units $(n=6)$ : small side-loops, large side-loops, controls, and rearing conditions of rainbow trout (Oncorhynchus mykiss) in the experiment

\begin{tabular}{lll}
\hline Characteristics & Value & Unit \\
\hline Water renewal: small side-loop, large side-loop, control & 250 & $\mathrm{~L} \mathrm{~kg} \mathrm{feed}^{-1} \mathrm{~d}^{-1}$ \\
& 100 & $\mathrm{~L} \mathrm{~d}$ \\
Small side-loop, large side-loop & 500 & $\mathrm{pcs}$ \\
Fish quantity per tank & 40 & $\mathrm{~kg} \mathrm{\textrm {m } ^ { 3 }}$ \\
Fish density: & $300-274$ & $\mathrm{~g}$ \\
Initial-final & $8.0-24.5$ & $\mathrm{~kg} \mathrm{~d}$ \\
Average fish weight & $13.2-43.7$ & $\mathrm{~mm}$ \\
Feed quantity & 0.1 & $1.7-2.5$ \\
Feed pellet size & & $\mathrm{mm}$ \\
\hline
\end{tabular}


Fig. 1 A flowchart of the experimental setup, showing a fish tank (FT), swirl separator, drum filter, fixed-bed reactor (FBBR), moving bed reactor (MBBR), trickling filter (TF), and a side-loop with a woodchip bioreactor (WCBR), and a sand filter (SF)

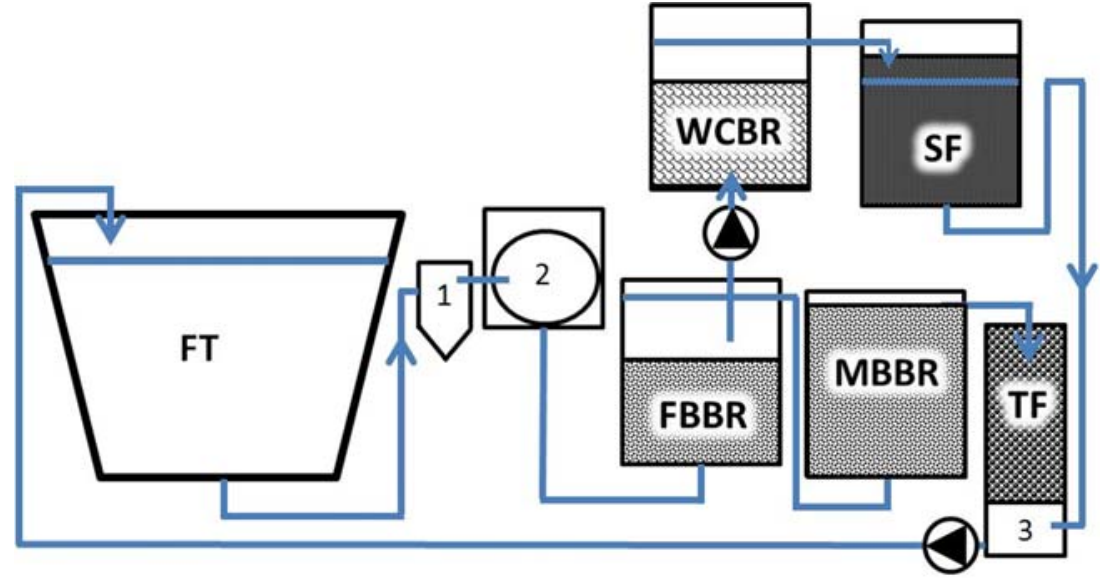

in weight to $43.7 \pm 1.0 \mathrm{~g}\left(24.5 \mathrm{~kg} \mathrm{~m}^{-3}\right)$ during the experiment. First, the fish were fed with Raisioaqua Circuit Red (Finland) $1.7 \mathrm{~mm}$, and after 4 weeks with $2.5-\mathrm{mm}$ pellets. The main ingredients of feed consisted of fish meal made of Baltic herring and sprat, soya meal, and horse bean, including 0.95 $1.15 \% \mathrm{P}$ and $7.52-7.84 \% \mathrm{~N}$ (Raisioaqua). During the experiment, feed was constantly added $0.1 \mathrm{~kg}^{\text {day }}{ }^{-1}$ to keep the input of nutrients into the systems constant (Table 1). However, there was an unintended $10 \%$ increase in the feeding rate at the experimental week 6 , after which it was returned back to $0.1 \mathrm{~kg} \mathrm{day}^{-1}$. On week 4 , an antibiotic orimycin was added (administered in feed) into the system for 10 days to treat the fish against an infection caused by Flavobacterium psychrophilum. There was an intermediate weighing after 5 weeks to adjust feeding according to the correct tank biomass. Feed was provided 12 times per day and light for $24 \mathrm{~h}$ per day. The fish were visually inspected on a daily basis, and any mortalities were removed and recorded.

\section{Sample collection}

Circulating water was collected from the fish tank once a week from the side-loop after the woodchip bioreactor, and after the sand filter. For the chemical analyses, water samples were collected in 250-mL high-density polyethylene (HDPE) plastic jars with HDPE plastic caps and stored at $-22^{\circ} \mathrm{C}$. For the elemental analyses, the samples were stored at $+2{ }^{\circ} \mathrm{C}$.

\section{Inorganic anions}

\section{Instrumentation and chemical analysis}

Prior to analysis, water samples were purified by running through a solid-phase extraction (SPE) cartridge (Phenomenex Strata ${ }^{\circledR}$ C18-E, $500 \mathrm{mg} / 3 \mathrm{~mL}, 55 \mu \mathrm{m}, 70 \AA$ ). The pretreated samples were further filtered through a $0.2-\mu \mathrm{m}$ syringe filter (13 mm Ø, cellulose, Teknokroma) to avoid blockages in the analysis.
All analyses were conducted on a Dionex DX-500 ion chromatography equipment (Dionex, Sunnyvale, CA, USA), consisting of a gradient pump (AG 40), an anion pre-column (Ion Pac ${ }^{\mathrm{TM}}$ AG11-HC-4 $\mu \mathrm{m}, 4 \mathrm{~mm} \times 25 \mathrm{~mm}$ ), an anion separation column (Ion Pac ${ }^{\mathrm{TM}}$ AS11-HC-4 $\mu \mathrm{m}, 4 \mathrm{~mm} \times 250 \mathrm{~mm}$ ), anion self-generating suppressor (ASRS 600, $4 \mathrm{~mm}$ ), an eluent generator (EG40), a conductivity detector (CD20), and an autosampler (AS50).

Elution was performed with a linear gradient from $14 \mathrm{mM}$ $\mathrm{KOH}$ for $5 \mathrm{~min}$ to $60 \mathrm{mM} \mathrm{KOH}$ over the course of $12 \mathrm{~min}$. After $4 \mathrm{~min}$ at $60 \mathrm{mM}$, concentration was decreased to $14 \mathrm{mM}$, taking $26 \mathrm{~min}$ in total. Eluent flow rate was $1.0 \mathrm{~mL} \mathrm{~min}^{-1}$ with the inlet pressure at about 2000 psi, column temperature $30{ }^{\circ} \mathrm{C}$, and sample injection volume $25 \mu \mathrm{L}$. Detection was performed with a suppressed conductivity detector and a suppressor current at $149 \mathrm{~mA}$.

\section{Method validation}

Sodium chloride $(\mathrm{NaCl})$, sodium nitrite $\left(\mathrm{NaNO}_{2}\right)$, sodium nitrate $\left(\mathrm{NaNO}_{3}\right)$, sodium sulfate $\left(\mathrm{Na}_{2} \mathrm{SO} 4\right)$, and disodium hydrogen phosphate $\left(\mathrm{Na}_{2} \mathrm{HPO}_{4}\right)$ were used to prepare standard solutions ( $\geq 99 \%$, Merck). Stock solutions of $5 \mathrm{mg} \mathrm{L}^{-1}$ or $10 \mathrm{mg} \mathrm{L}^{-1}\left(\mathrm{Na}_{2} \mathrm{SO}_{4}\right)$ were prepared by diluting an accurate amount of pure standard in UHQ water (internal resistance $\geq$ $18.2 \Omega$ at $25^{\circ} \mathrm{C}$ ) by Millipore (Bedford, MA, USA) and filtered through a $0.2-\mu \mathrm{m}$ syringe filter.

LOD, LOQ, linearity Limit of detection (LOD) and limit of quantification (LOQ) were based on signal-to-noise $(\mathrm{S} / \mathrm{N})$ ratio of 3 and 10, respectively. The results were reported as injected to the detector (Supplementary Table S2). LODs ranged between $0.09-1.04 \mathrm{mg} \mathrm{L}^{-1}$, and LOQs 0.10 $1.15 \mathrm{mg} \mathrm{L}^{-1}$.

Linearity of the method was evaluated separately for each compound by plotting the concentrations of five standard solutions against their peak areas. Concentrations ranged between 1 and $100 \mathrm{mg} \mathrm{L}^{-1}$. Linear regression analysis was 
conducted for each standard curve at the confidence interval of $95 \%$ (Supplementary Table S2). The regression coefficients were all close to 1 , indicating a good linearity. The equations of linearity analysis were used for the quantification of sample concentrations.

Precision Precision of the method was evaluated by performing repeated analyses on following days. A sample spiked with standard solution was analyzed five times during 5 days. Based on the results, the interday and intraday repeatability and precision were calculated (Supplementary Table S3). An analysis of variance (ANOVA) was performed, and the precisions were calculated according to Eqs. 1 and 2, $\sigma_{\mathrm{r}}$ being the residual error, $\sigma_{\mathrm{A}}$ day to day error, and $\bar{x}$ mean of response. The results were expressed as relative standard deviation (RSD, \%) according to Destandau et al. (2005) and showed good $(<1 \%)$ or intermediate $(1-5 \%)$ degree of repeatability.

$$
\begin{aligned}
& R S D_{\text {intraday }}(\%)=\frac{\sigma_{r}}{\bar{x}} 100 \\
& R S D_{\text {interday }}(\%)=\frac{\sigma_{A}}{\bar{x}} 100
\end{aligned}
$$

Accuracy The accuracy of the method was evaluated by comparing the results of introduced standard solutions and calculated results based on the equations of linearity analysis. The results of introduced and calculated concentrations were in good agreement with an error of less than $5 \%$ (Supplementary Table S4). Only for nitrate, once the error of recovery was more than $5 \%(5.2 \%)$.

\section{Fatty acids}

\section{Chemicals and standards}

HPLC grade $(\geq 99,8 \%)$ methanol, $n$-hexane, pyridine, methyl tert-butyl ether (MTBE), and $\mathrm{KOH}$ granules (max. $0.002 \%$ $\mathrm{Na}$ ) were purchased from Merck (Darmstadt, Germany), while 25\% o-bis-(trimethylsilyl)-trifluoroacetamide (BSTFA) with $1 \%$ trimethyl chlorosilane (TMCS) from Alfa Aesar (Heysham, Lancashire, UK). Heneicosanoic acid $\left(\mathrm{C}_{21} \mathrm{H}_{42} \mathrm{O}_{2}\right.$, purity $\geq 99 \%$, Merck, Saint Louis, MO, USA) was used as an internal standard. Stock solution of $1 \mathrm{mg} \mathrm{mL}^{-1}$ was prepared by dissolving an accurate amount of pure standard in MTBE and stored at $+2{ }^{\circ} \mathrm{C}$.

\section{Sample preparation and analysis}

First, the $\mathrm{pH}$ of the samples was adjusted to below $\mathrm{pH} 3$ with a few drops of $1 \mathrm{M} \mathrm{HCl}$ (aq) to ensure the acidic form of fatty acids if present. For the GC-FID analysis, $4 \mathrm{~mL}$ of sample was measured in a screw-capped Kimax tube for liquid-liquid extraction (LLE). $2 \mathrm{~mL}$ of MTBE was added, stirred thoroughly, centrifuged at $300 \mathrm{~g}$ for $5 \mathrm{~min}$ (Centrifuge 1.0), and the clear MTBE layer (supernatant) was collected. A volume of $30 \mu \mathrm{L}$ of internal standard, heneicosanoic acid $\left(95 \mu \mathrm{g} \mathrm{mL} \mathrm{m}^{-1}\right.$ in MTBE), was added. The samples were prepared as triplicates and the extraction procedure was repeated three times. Finally, the extracts were evaporated to dryness under a gentle stream of nitrogen. The extracted compounds were derivatized to trimethylsilyl esters. For the derivatization, $760 \mu \mathrm{L}$ of pyridine (dried with $\mathrm{KOH}$ granules) and $330 \mu \mathrm{L}$ of BSTFA+ TMCS were added to the evaporation residue. The solution was heated in an oven at $70{ }^{\circ} \mathrm{C}$ for $1 \mathrm{~h}$.

The sample was analyzed with a GC-FID instrument (Shimadzu GC-2010/FID), equipped with a ZB-5MSi column (7HG-G018-11, $30 \mathrm{~m} \times 0.25 \mathrm{~mm} \times 0.25 \mu \mathrm{m})$, and an autosampler (AOC-20i). The oven temperature was held at $70{ }^{\circ} \mathrm{C}$ for $1 \mathrm{~min}$ to equilibrate, heated to $250{ }^{\circ} \mathrm{C}$ over the course of $10 \mathrm{~min}$, heated to $300{ }^{\circ} \mathrm{C}$ in $5 \mathrm{~min}$, and held for another $5 \mathrm{~min}$. The FID was operated at $300{ }^{\circ} \mathrm{C}$ with a sampling rate of $40 \mathrm{msec}$, helium flow $40 \mathrm{~mL} \mathrm{~min}^{-1}$, and air flow $400 \mathrm{~mL} \mathrm{~min}^{-1}$. All injections were made in the splitless mode, injecting $1 \mu \mathrm{L}$ of sample.

The compounds were identified by using an Agilent 6890 series/5973 N GC/MSD (Palo Alto, CA, USA) system with a mass spectrometric detector under electron ionization $(70 \mathrm{eV})$, and a Phenomenex Zebron ZB-5MSi (Torrance, CA, USA) capillary column $(30 \mathrm{~m} \times 0.25 \mathrm{~mm} \times 0.25 \mu \mathrm{m})$. The same oven temperature program was used as with the GC-FID equipment. For the identification of chromatogram peaks, the proper interpretation of the mass spectra was used based on the National Institute of Standards and Technology [NIST] mass spectral library.

\section{Method validation}

LOD, LOQ, linearity LOD and LOQ were calculated for the standard solution based on signal-to-noise $(\mathrm{S} / \mathrm{N})$ ratio of 3 and 10 , resulting for LOD $0.12 \mathrm{mg} \mathrm{L}^{-1}$ and for LOQ $0.16 \mathrm{mg} \mathrm{L}^{-1}$.

Linearity of the method was evaluated by plotting five concentrations ranging between 0.3 and $1.1 \mathrm{mg} \mathrm{L}^{-1}$ of internal standard solution (heneicosanoic acid) against their peak areas. Linear regression analysis was conducted for the standard curve at the confidence interval of $95 \%$. The regression coefficient was 0.9934 , indicating a good linearity. The equation of linearity analysis was used for the quantification of sample concentrations.

Accuracy and precision Intraday and interday precision was calculated for low $\left(0.3 \mathrm{mg} \mathrm{L}^{-1}\right)$ and high $\left(1.1 \mathrm{mg} \mathrm{L}^{-1}\right)$ concentration levels. All analyses were performed in a sample matrix spiked with the internal standard heneicosanoic acid 
as previously reported. Intraday precision of low $\left(0.3 \mathrm{mg} \mathrm{L}^{-1}\right)$ concentration was $2.7 \%$, and interday precision $2.7 \%$. For the high concentration $\left(1.1 \mathrm{mg} \mathrm{L}^{-1}\right), 1.4 \%$ intraday and $1.2 \%$ interday precisions were reached. The results were expressed as relative standard deviation (RSD, $\%, n=5$ ) and showed intermediate $(1-5 \%)$ degree of repeatability.

Matrix effect Matrix effects were determined in circulating water according to Eq. 3 (Garcia-Ac et al. 2009), where $\mathrm{SW}_{\mathrm{S}}$ is the analyte peak in the spiked circulating water, $\mathrm{SW}_{\mathrm{NS}}$ analyte peak in the non-spiked circulating water, and $\mathrm{W}$ the analyte peak in spiked UHQ water. A value of $100 \%$ indicates no matrix effect, while over $100 \%$ indicates enhancement and below $100 \%$ signal suppression due to matrix effects (Garcia-Ac et al. 2009).

Matrix, $\%=\left(\frac{S W_{S}-S W_{N S}}{W}\right) 100$

The matrix effect was studied at five concentrations in the range of $0.3-1.1 \mathrm{mg} \mathrm{L}^{-1}$. The matrix effect ranged between 98 and $103 \%$, showing minor matrix effect.

\section{Elemental analyses}

\section{Sample digestion and ICP-MS analysis}

A microwave acidic digestion of the circulating water samples was performed according to US EPA 2007, method 3015. For practical reasons, weight of the sample was reduced by half to $18 \mathrm{~mL} ; 3 \mathrm{~mL}$ of $\mathrm{HNO}_{3}(65 \%$, Fluka) was added and placed into a polytetrafluoroethylene (PTFE) tube. The tubes were capped and heated in a CEM Mars 6 (Hosmed) microwave oven to $170{ }^{\circ} \mathrm{C}$ over the course of $10 \mathrm{~min}$ and held for another $10 \mathrm{~min}$ at $170{ }^{\circ} \mathrm{C}$ (US EPA 2007, method 3015). The samples were left to cool down to $30^{\circ} \mathrm{C}$, transferred into a 40 -mL flask and brought to volume with UHQ water. Quality assurance of the digestion method was achieved by performing the analysis of spiked samples and method blanks. The samples were gravimetrically prepared in $1 \% \mathrm{HNO}_{3}(w / \mathrm{w})$ prior to inductively coupled plasma mass chromatography (ICP-MS) analysis. Samples were prepared and analyzed in duplicate, their recovery ranging between $94 \%$ and $105 \%$ for all elements.

Measurements were performed with a quadrupole-based Perkin Elmer NexION® 350 D ICP-MS system with an octapole collision cell and baffled cyclone electrospray ionization (ESI) cooled to $+2{ }^{\circ} \mathrm{C}$. The operating conditions and specifications were listed in Table 2. Before use, the ICP-MS was tuned with a $1 \mu \mathrm{g} \mathrm{L}^{-1}$ tuning solution (Perkin Elmer NexION Setup Solution N8145051). A standard solution containing the selected elements $(\mathrm{Al}, \mathrm{Cd}, \mathrm{Co}, \mathrm{Cu}, \mathrm{Mn}, \mathrm{Ni}$, and $\mathrm{Pb}$ ) was prepared at concentration $100 \mu \mathrm{g} \mathrm{L}^{-1}\left(1 \% \mathrm{NHO}_{3}, w / \mathrm{w}\right)$, while an internal standard solution $(\mathrm{Bi}, \mathrm{In}, \mathrm{Ga}$, and $\mathrm{Ge}$, $100 \mu \mathrm{g} \mathrm{L}^{-1}$ in $1 \% \mathrm{NHO}_{3}$, w/w) was used as a reference and added via a mixing T-piece. All solutions were gravimetrically prepared in $1 \% \mathrm{HNO}_{3}, \mathrm{w} / \mathrm{w}$ ).

LOD, LOQ, linearity As previously mentioned, LODs, LOQs, and linearities $\left(\mathrm{R}^{2}\right)$ were determined for the selected elements (Supplementary Table S5). The indicators were calculated with four concentrations of the standard solution: $0.5 \mu \mathrm{g} \mathrm{L}^{-1}, 1 \mu \mathrm{g} \mathrm{L}^{-1}, 5 \mu \mathrm{g} \mathrm{L}{ }^{-1}$, and $10 \mu \mathrm{g} \mathrm{L}^{-1}$. For all selected elements, LODs ranged between $0.02-0.27 \mu \mathrm{g} \mathrm{L}^{-1}$ and LOQs between $0.07-0.92 \mu \mathrm{g} \mathrm{L}^{-1}$, except $2.8 \mu \mathrm{g} \mathrm{L}^{-1}$ for aluminum. The regression coefficients $\left(\mathrm{R}^{2}\right)$ were close to 1 for all selected elements, indicating a good linearity. The equations of linearity analysis were used for the quantification of sample concentrations.

\section{ICP-OES analysis}

Elemental analyses were performed with a Perkin-Elmer (Optima 8300, Norwalk, CT, USA) inductively coupled plasma optical emission spectrometer (ICP-OES) equipped with a glass concentric nebulizer and a cyclonic spray chamber. The plasma was viewed axially for potassium (K), phosphorous $(\mathrm{P})$, and sulfur $(\mathrm{S})$, but radially in the case of calcium $(\mathrm{Ca})$ and magnesium $(\mathrm{Mg})$. The analytical parameters of the instrument were: RF power $1.5 \mathrm{~kW}$, plasma gas flow rate $8 \mathrm{~L} \mathrm{~min}^{-1}$, auxiliary gas flow rate $0.21 \mathrm{~min}^{-1}$, nebulizer gas flow rate $0.6 \mathrm{~L} \mathrm{~min}^{-1}$, rinse time $10-15 \mathrm{~s}$, and sample uptake $1.5 \mathrm{~mL} \mathrm{~min}^{-1}$. All reagents used were of analytical grade. The measurements were performed in $1 \% \mathrm{HNO}_{3}$. An external calibration was used by preparing $0.5,1,10,30$, and $60 \mathrm{mg} \mathrm{L}^{-1}$ standard solutions, containing $\mathrm{Ca}, \mathrm{K}, \mathrm{Mg}$, $\mathrm{P}$, and $\mathrm{S}$. Accepted relative standard deviation of three replicate measurements was less than $20 \%$ with an external calibration. Optimal analytical wavelengths for the measurements were (nm): Ca (315.887), K (766.490), Mg (279.077), P (177.50), and S (182.563). The LODs, LOQs, and linearities were listed in Supplementary Table S6, ranging from 0.29 to $2.2 \mathrm{mg} \mathrm{L}^{-1}$ (LODs) and from 1.3 to $8.5 \mathrm{mg} \mathrm{L}^{-1}$ (LOQs).

\section{Toxicity}

The toxicity tests were conducted in the laboratory of Ecotoxicology and Risk Assessment, Finnish Environmental Institute (SYKE) for water samples collected from the inlet water from Lake Peurunka, systems with small side-loops, large side-loops, and controls, each with two replicates. The samples were taken right after the start-up of the experiment, representing the most concentrated sample type. Control water (UHQ with 23 different vitamins, and micro- and macronutrients) was used for the control test of acute toxicity to study the fitness of the population. 
Table 2 Instrumental parameters and measurement conditions for Perkin Elmer NexION 350 D ICP-MS spectrometer

\begin{tabular}{ll}
\hline Isotopes monitored & $\mathrm{Al}^{27}, \mathrm{Cd}^{111}, \mathrm{Cd}^{112}, \mathrm{Cd}^{114}, \mathrm{Co}^{59}, \mathrm{Cu}^{63}, \mathrm{Cu}^{65}, \mathrm{Mn}^{55}, \mathrm{Ni}^{58}, \mathrm{Ni}^{60}, \mathrm{~Pb}^{206}, \mathrm{~Pb}^{207}, \mathrm{~Pb}^{208}$ \\
Spray chamber & Cyclonic \\
RF power & $1600 \mathrm{~W}$ \\
Plasma gas flow rate & $18 \mathrm{~L} \mathrm{~min}$ min $^{-1}$ \\
Nebulizer & PFA-ST \\
Ar nebulizer gas flow rate & $0.85-0.9 \mathrm{~L} \mathrm{~min}{ }^{-1}$ \\
Injector & Perkin Elmer 1.8-mm I.D. Sapphire \\
Injection volume & $1.5 \mathrm{~mL}$ \\
Sampling cone & $\mathrm{Ni}, 1-\mathrm{mm}$ aperture diameter \\
Skimmer cone & $\mathrm{Ni}, 0.4-\mathrm{mm}$ aperture diameter \\
Scan mode & Peak hopping \\
Dwell time & $50 \mathrm{~s}$ \\
Sweeps per reading & 24 \\
Integration time & $1200 \mathrm{~ms}$ \\
Readings per replicate & 3 \\
\hline
\end{tabular}

Acute toxicity test for Daphnia longispina was modified from standard ISO 6341. It is based on the survival of 24-h old cubs in $10 \mathrm{ml}$ of undiluted sample solution. The tests were performed with five cubs and five repetitions per treatment. Immobile cubs were counted after $24 \mathrm{~h}$, and again after $48 \mathrm{~h}$.

The inhibitory effect of aqueous samples was studied with standard test ISO 11348-3:2007 for luminescent bacteria Vibrio fischeri. It is based on the measurement of luminescence in constant conditions since the luminescence decreases in the case of exposure to hazardous substances. Since Vibrio fischeri naturally occurs in sea water, the salt content of undiluted samples was adjusted to $2 \%$ with $\mathrm{NaCl}$ and $\mathrm{pH}$ to $6-8.5$. The test was performed with 1234-500 Aboatox $^{\mathrm{TM}}$ kit (Aboatox, Finland) stored at $-20{ }^{\circ} \mathrm{C}$.

\section{Results and discussion}

\section{Fish and feeding}

There were no differences between the control systems and those with the woodchip bioreactor and the sand filter, when comparing the feed conversion ratio, specific growth rate and fish mortality (Table 3). The fish showed no unusual behavior or signs of stress or discomfort. This suggests that the conditions were suitable for the raised species.

\section{Denitrification}

At the beginning of the experiment, nitrate removal reached $85 \%$ in the woodchip bioreactor, and an additional $48 \%$ decrease from the remaining $\mathrm{NO}_{3}-\mathrm{N}$ in the sand filter (Fig. 2). This equals the nitrate removal rate of $19.1 \mathrm{~g} \mathrm{NO}_{3}-\mathrm{N} \mathrm{m}^{-3}$ woodchips $\mathrm{d}^{-1}$ in the small side-loop and $16.7 \mathrm{~g} \mathrm{NO}_{3}-\mathrm{N} \mathrm{m}^{-3}$ $\mathrm{d}^{-1}$ in the large side-loop, being in the upper range reported by Schipper et al. (2010b). However, the nitrate-nitrogen removal decreased during the experiment and after 9 weeks only up to $37 \%$ efficiencies were reached. The nitrate removal rates decreased from $19.1 \mathrm{~g} \mathrm{~N} \mathrm{~m}^{-3} \mathrm{~d}^{-1}$ (week 3) to $15.4 \mathrm{~g} \mathrm{~N} \mathrm{~m}^{-3} \mathrm{~d}^{-1}$ (week 6), and $10.0 \mathrm{~g} \mathrm{~N} \mathrm{~m}^{-3} \mathrm{~d}^{-1}$ (week 9), respectively, in the small side-loop, while from $16.9 \mathrm{~g} \mathrm{~N} \mathrm{~m}^{-3} \mathrm{~d}^{-1}$ (week 3) to $14.1 \mathrm{~g} \mathrm{~N} \mathrm{~m}^{-3} \mathrm{~d}^{-1}$ (week 6), and $7.4 \mathrm{~g} \mathrm{~N} \mathrm{~m}^{-3} \mathrm{~d}^{-1}$ (week 9) in the large side-loop. The results suggest that the dimensioning of the woodchip bioreactor was insufficient for the nitrogen load. This is supported by the fact that nitrogen removal efficiencies were lower in the large side-loop.

Nitrate removal rates of 5.1-21.0 $\mathrm{g} \mathrm{N} \mathrm{m}^{-3} \mathrm{~d}^{-1}$ have been observed in woodchip bioreactors (Robertson 2010; Hoover

Table 3 Feed conversion ratio, specific growth rate, and mortality $( \pm$ SD) during the experiment

\begin{tabular}{|c|c|c|c|c|c|c|}
\hline \multirow[t]{2}{*}{ Treatment } & \multirow{2}{*}{$\begin{array}{l}\text { Feed conversion ratio } \\
\text { Week } 2-5\end{array}$} & \multicolumn{3}{|c|}{ Specific growth rate $\left(\%\right.$ day $\left.^{-1}\right)$} & \multicolumn{2}{|c|}{ Mortality (\%) } \\
\hline & & Week 6-9 & Week 2-5 & Week 6-9 & Week 2-5 & Week 6-9 \\
\hline Control & $0.95 \pm 0.02$ & $0.97 \pm 0.02$ & $2.0 \pm 0.0$ & $0.99 \pm 0.03$ & $5.7 \pm 2.0$ & $3.3 \pm 0.2$ \\
\hline Small side-loop & $1.00 \pm 0.01$ & $1.00 \pm 0.03$ & $2.0 \pm 0.01$ & $0.96 \pm 0.01$ & $6.7 \pm 1.1$ & $2.1 \pm 0.0$ \\
\hline Large side-loop & $0.93 \pm 0.05$ & $0.91 \pm 0.01$ & $2.0 \pm 0.07$ & $1.01 \pm 0.05$ & $3.9 \pm 0.0$ & $1.5 \pm 0.5$ \\
\hline
\end{tabular}



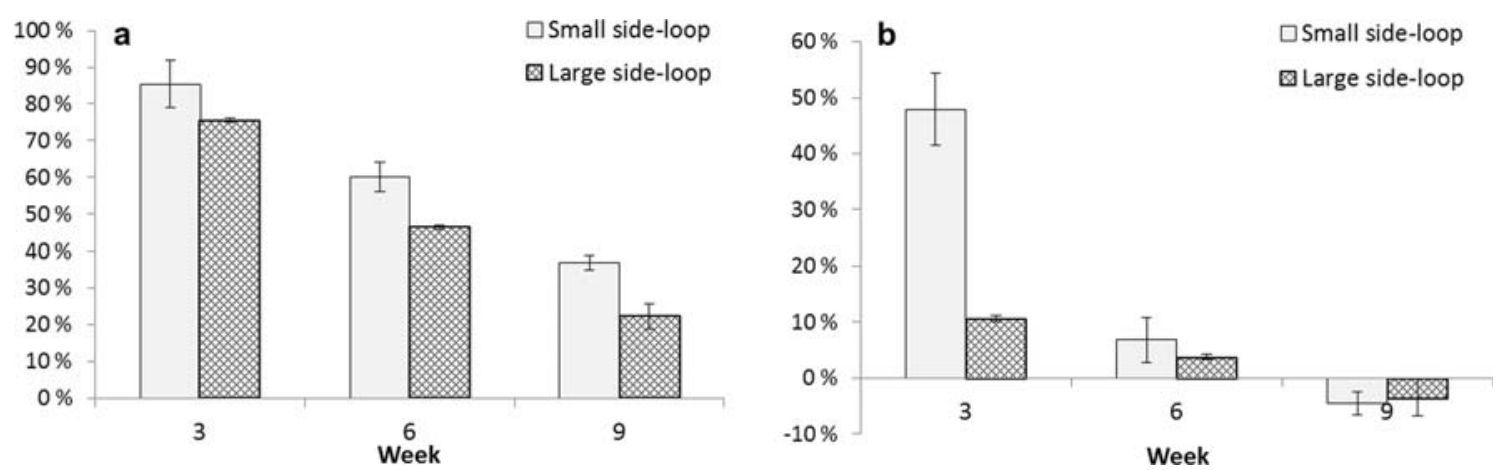

Fig. 2 Nitrate removal $(\%, \pm \mathrm{SD}, n=24)$ in the woodchip bioreactor (a) and in the sand filter (b) after 3, 6, and 9 weeks of the experiment

et al. 2016; von Ahnen et al. 2016). The removal rate can decrease up to $50 \%$ during the first year of operation (Robertson 2010). In this experiment, the removal rates were similar compared to previously reported, however, excluding the rapid decrease in nitrate removal rate. However, there might have been easily dissolving carbon in the woodchips, which induced higher removal rates at the beginning of the experiment. Therefore, the system might have only reached a steady state at experimental week 7 , after the nitrate leaching from the bioreactors was leveled (Fig. 3b).

At the experimental week 4 , an antibiotic orimycin was added to the system to treat the fish against infection caused by Flavobacterium psychrophilum for 10 days. Additionally, there was an unintended $10 \%$ increase in the feeding rate at the
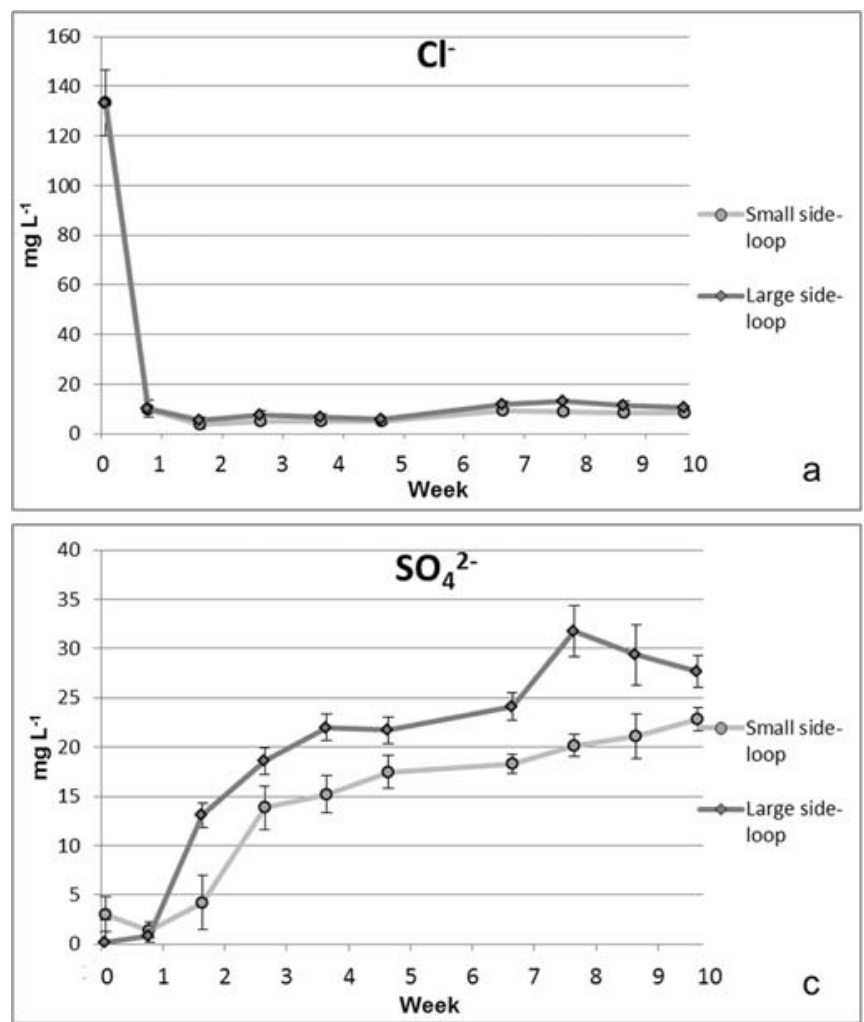

experimental week 6 . The antibiotic addition might have harmed the microbial population in the nitrifying bioreactor, but either is unlikely to cause the decreased efficiencies in the latter part of the experiment. In this study, $\mathrm{N}_{2} \mathrm{O}, \mathrm{NO}_{2}$, and $\mathrm{NH}_{4}$ were not directly monitored from the outlets of the woodchip bioreactors, leaving the proportions of nitrogen end-products unconfirmed.

\section{Anions}

At the beginning of the experiment, over $140 \mathrm{mg} \mathrm{L}^{-1}$ concentrations of chloride were found immediately after starting the experiment (Fig. 3a). Concentrations of readily water-soluble chloride were quickly reduced and remained at about
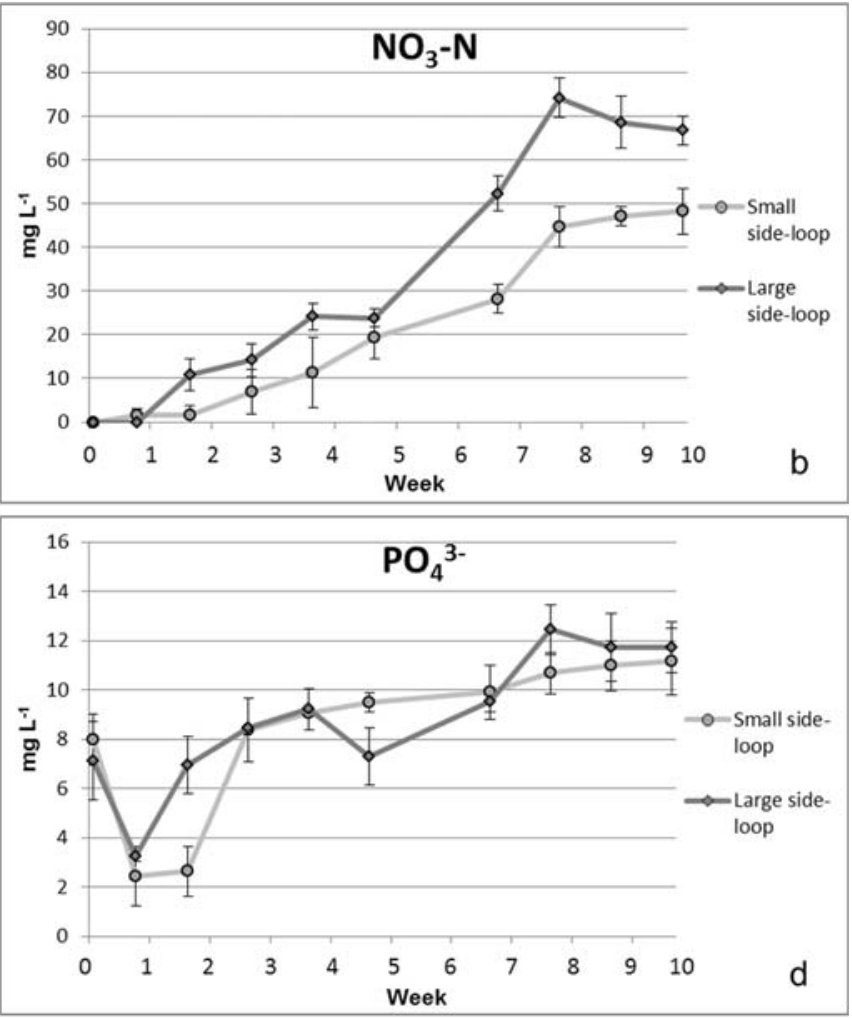

Fig. 3 Concentrations of chloride $\left(\mathrm{Cl}^{-}\right.$, a), nitrate-N $\left(\mathrm{NO}_{3}-\mathrm{N}, \mathrm{b}\right)$, sulfate $\left(\mathrm{SO}_{4}{ }^{2-}, \mathrm{c}\right)$, and phosphate $\left(\mathrm{PO}_{4}{ }^{3-}, \mathrm{d}\right)\left(\mathrm{mg} \mathrm{L}{ }^{-1}, \pm \mathrm{SD}, n=4\right)$ in circulating water after the woodchip bioreactor during the 10 weeks of the experiment 
$10 \mathrm{mg} \mathrm{L}^{-1}$ level throughout the rest of the experiment. Birch wood contains micronutrients, originating from the soil in the place of growth. Micronutrients, such as chloride, typically occur in wood as cations in aqueous solution (Werkelin et al. 2005). For example, Werkelin et al. (2005) reported 70$110 \mathrm{mg} \mathrm{Cl} \mathrm{kg}{ }^{-1}$ in dry birch (Betula pubescens) wood and $40-330 \mathrm{mg} \mathrm{kg}^{-1}$ in birch bark, showing that the woodchips are the most likely source of chloride in the system. Other sources include fish feed and metabolic products of fish (Turcios and Papenbrock 2014).

After the first month of experiment, the nitrate levels, calculated as $\mathrm{NO}_{3}-\mathrm{N}$, remained below $30 \mathrm{mg} \mathrm{L}^{-1}$, but then increased rapidly up to $75 \mathrm{mg} \mathrm{L}^{-1}$ (Fig. 3b). The concetrations of nitrate $\left(\mathrm{NO}_{3}-\mathrm{N}\right)$ increased in the small side-loop up to $50 \mathrm{mg} \mathrm{L}^{-1}$ and in the large side-loop up to $75 \mathrm{mg} \mathrm{L}^{-1}$ at the end of the experiment. At first, the concentrations remained lower than those in the tank water but increased up to the same level (Supplementary Table S1). Additionally, denitrification efficiency decreased after 3 weeks of the experiment (Fig. 2), while at that point, concentrations of nitrate in the side-loops started to increase (Fig. 3b).
After the woodchip bioreactor, concentrations of sulfate were first below $20 \mathrm{mg} \mathrm{L}^{-1}$ but increased up to 20 $35 \mathrm{mg} \mathrm{L}^{-1}$ range towards the end of the experiment (Fig. 3c). Levels of phosphate remained more stable throughout the experiment and increased only moderately up to $12 \mathrm{mg} \mathrm{L}^{-1}$ in the end of the experiment (Fig. 3d). After the sand filter, the concentrations of sulfates increased above $20 \mathrm{mg} \mathrm{L}^{-1}$ and phosphates above $10 \mathrm{mg} \mathrm{L}^{-1}$ over the course of the experiment (Supplementary Fig. S1). Concentrations of chloride remained below $15 \mathrm{mg} \mathrm{L}^{-1}$, but nitrate $\left(\mathrm{NO}_{3}-\mathrm{N}\right)$ increased up to $65 \mathrm{mg} \mathrm{L}^{-1}$ at the end of the experiment.

\section{Fatty acids}

The long-chained unsaturated fatty acids are known to be toxic to salmonids (Leach and Thakore 1978). Additionally, resin acids originating from softwood are acutely very toxic to fish (Oikari et al. 1983; Peng and Roberts 2000). Therefore, birch woodchips were chosen for the woodchip bioreactor, resulting in no resin acids, or unsaturated fatty acids were found in the circulating water (Fig. 4).
Fig. 4 Concentrations $\left(\mathrm{mg} \mathrm{L}^{-1}, \pm\right.$ $\mathrm{SD}, n=4)$ of benzoic acid, hexadecanoic acid, and octadecanoic acid in the circulation water, after the woodchip bioreactor (a) and the sand filter (b), in small and large side-loops during the 10 weeks of the experiment
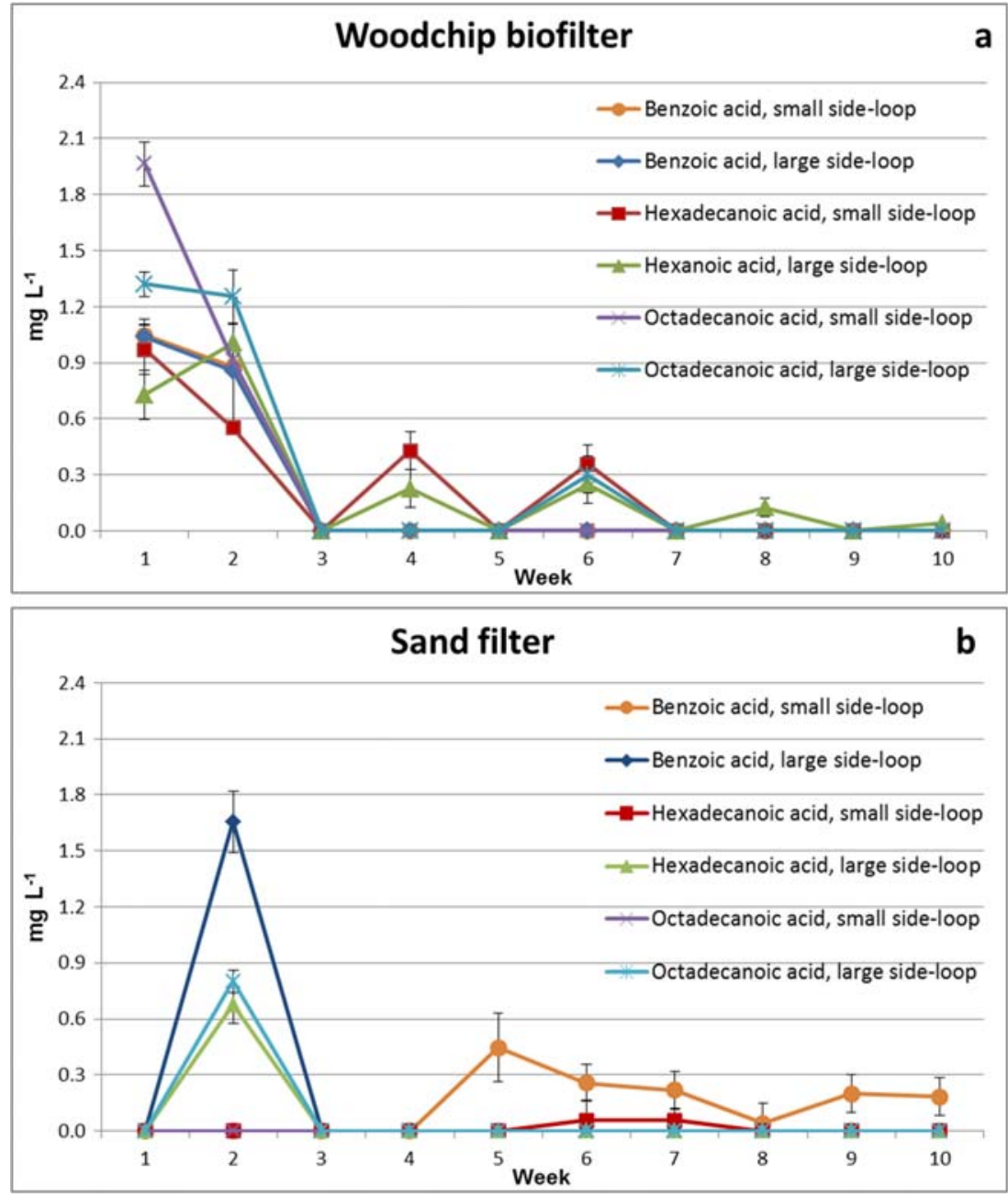
Table 4 Concentrations of selected trace elements in circulating water during the experiment, after the woodchip bioreactor and after the sand filter $\left(\mu \mathrm{g} \mathrm{L} \mathrm{L}^{-1}, \pm \mathrm{SD}, n=4\right)$

\begin{tabular}{|c|c|c|c|c|c|c|c|c|c|}
\hline Week & 1 & 2 & 3 & 4 & 5 & 7 & 8 & 9 & 10 \\
\hline \multicolumn{10}{|c|}{ From woodchip bioreactor, small side-loop } \\
\hline $\mathrm{Al}, \mu \mathrm{g} \mathrm{L} \mathrm{L}^{-1}$ & $<$ LOD & $39 \pm 8.1$ & $2.7 \pm 1.3$ & $<$ LOD & $<$ LOD & $<\mathrm{LOD}$ & $<$ LOD & $<$ LOD & $<$ LOD \\
\hline $\mathrm{Cd}, \mu \mathrm{g} \mathrm{L}{ }^{-1}$ & $0.32 \pm 0.1$ & $0.12 \pm 0.1$ & $0.03 \pm 0.03$ & $<\mathrm{LOD}^{*}$ & $<$ LOD & $<$ LOD & $<$ LOD & $<$ LOD & $<$ LOD \\
\hline Co, $\mu \mathrm{g} \mathrm{L}^{-1}$ & $0.5 \pm 0.3$ & $0.2 \pm 0.1$ & $0.04 \pm 0.01$ & $0.2 \pm 0.2$ & $<$ LOD & $<$ LOD & $<$ LOD & $<$ LOD & $<$ LOD \\
\hline $\mathrm{Cu}, \mu \mathrm{g} \mathrm{L}{ }^{-1}$ & $<$ LOD & $11 \pm 1.1$ & $2.3 \pm 0.4$ & $1.4 \pm 0.9$ & $21 \pm 6.5$ & $12 \pm 11$ & $8.8 \pm 6.5$ & $8.2 \pm 3.4$ & $4.5 \pm 1.5$ \\
\hline $\mathrm{Mn}, \mu \mathrm{g} \mathrm{L}^{-1}$ & $1100 \pm 45$ & $69 \pm 6.2$ & $10 \pm 1.4$ & $64 \pm 1.6$ & $99 \pm 0.2$ & $60 \pm 14$ & $54 \pm 5.4$ & $18 \pm 17$ & $55 \pm 6.9$ \\
\hline $\mathrm{Ni}, \mu \mathrm{g} \mathrm{L}{ }^{-1}$ & $<$ LOD & $1.2 \pm 0.2$ & $17 \pm 14$ & $<$ LOD & $<$ LOD & $<$ LOD & $<$ LOD & $<$ LOD & $<$ LOD \\
\hline $\mathrm{Pb}, \mu \mathrm{g} \mathrm{L}^{-1}$ & $<$ LOD & $0.9 \pm 0.2$ & $<\mathrm{LOD}$ & $<$ LOD & $<$ LOD & $<$ LOD & $<$ LOD & $<$ LOD & $<$ LOD \\
\hline \multicolumn{10}{|c|}{ From woodchip bioreactor, large side-loop } \\
\hline $\mathrm{Al}, \mu \mathrm{g} \mathrm{L} \mathrm{L}^{-1}$ & $<\mathrm{LOD}$ & $55 \pm 7.0$ & $1.1 \pm 1.1$ & $<$ LOD & $<\mathrm{LOD}$ & $<$ LOD & $<\mathrm{LOD}$ & $<$ LOD & $<$ LOD \\
\hline $\mathrm{Cd}, \mu \mathrm{g} \mathrm{L}^{-1}$ & $0.10 \pm 0.1$ & $0.45 \pm 0.4$ & $0.01 \pm 0.01$ & $0.12 \pm 0.03$ & $0.18 \pm 0.05$ & $<$ LOD & $<\mathrm{LOD}$ & $<\mathrm{LOD}$ & $<$ LOD \\
\hline Co, $\mu \mathrm{g} \mathrm{L}^{-1}$ & $0.3 \pm 0.1$ & $0.5 \pm 0.6$ & $0.03 \pm 0.01$ & $0.2 \pm 0.1$ & $<\mathrm{LOD}$ & $<$ LOD & $<\mathrm{LOD}$ & $<$ LOD & $<\mathrm{LOD}$ \\
\hline $\mathrm{Cu}, \mu \mathrm{g} \mathrm{L}^{-1}$ & $<$ LOD & $16 \pm 3.4$ & $2.3 \pm 0.1$ & $10 \pm 2.2$ & $6.5 \pm 3.0$ & $7.2 \pm 2.5$ & $7.8 \pm 0.6$ & $6.0 \pm 1.8$ & $4.7 \pm 1.1$ \\
\hline $\mathrm{Mn}, \mu \mathrm{g} \mathrm{L}^{-1}$ & $1100 \pm 180$ & $120 \pm 5.4$ & $1.4 \pm 1.0$ & $18 \pm 14$ & $99 \pm 1.5$ & $39 \pm 4.9$ & $28 \pm 2.0$ & $30 \pm 2.5$ & $72 \pm 4.9$ \\
\hline $\mathrm{Ni}, \mu \mathrm{g} \mathrm{L}^{-1}$ & $<$ LOD & $1.2 \pm 0.4$ & $63 \pm 9.6$ & $<$ LOD & $<\mathrm{LOD}$ & $<$ LOD & $<\mathrm{LOD}$ & $<$ LOD & $<$ LOD \\
\hline $\mathrm{Pb}, \mu \mathrm{g} \mathrm{L}^{-1}$ & $<$ LOD & $0.6 \pm 0.1$ & $<\mathrm{LOD}$ & $<$ LOD & $<\mathrm{LOD}$ & $<$ LOD & $<\mathrm{LOD}$ & $<$ LOD & $<\mathrm{LOD}$ \\
\hline \multicolumn{10}{|c|}{ From sand filter, small side-loop } \\
\hline $\mathrm{Al}, \mu \mathrm{g} \mathrm{L}^{-1}$ & $3800 \pm 970$ & $81 \pm 32$ & $2.0 \pm 0.5$ & $<$ LOD & $<\mathrm{LOD}$ & $<$ LOD & $<\mathrm{LOD}$ & $<$ LOD & $<$ LOD \\
\hline $\mathrm{Cd}, \mu \mathrm{g} \mathrm{L}^{-1}$ & $<$ LOD & $0.15 \pm 0.05$ & $0.02 \pm 0.01$ & $<$ LOD & $<\mathrm{LOD}$ & $<$ LOD & $<\mathrm{LOD}$ & $<$ LOD & $<\mathrm{LOD}$ \\
\hline Co, $\mu \mathrm{g} \mathrm{L}^{-1}$ & $4.8 \pm 0.9$ & $0.2 \pm 0.1$ & $0.3 \pm 0.02$ & $1.3 \pm 0.6$ & $1.6 \pm 0.9$ & $<$ LOD & $<$ LOD & $0.6 \pm 0.2$ & $1.0 \pm 0.2$ \\
\hline $\mathrm{Cu}, \mu \mathrm{g} \mathrm{L}^{-1}$ & $<\mathrm{LOD}$ & $12 \pm 0.7$ & $3.2 \pm 0.6$ & $19 \pm 11$ & $21 \pm 7.2$ & $12 \pm 2.9$ & $16 \pm 1.4$ & $15 \pm 6.0$ & $11 \pm 3.5$ \\
\hline $\mathrm{Mn}, \mu \mathrm{g} \mathrm{L}^{-1}$ & $330 \pm 49$ & $21 \pm 8.7$ & $26 \pm 3.3$ & $24 \pm 4.5$ & $9.3 \pm 0.2$ & $91 \pm 8.4$ & $160 \pm 31$ & $280 \pm 6.8$ & $190 \pm 1.0$ \\
\hline $\mathrm{Ni}, \mu \mathrm{g} \mathrm{L}^{-1}$ & $<$ LOD & $1.4 \pm 0.2$ & $0.4 \pm 0.1$ & $<$ LOD & $<$ LOD & $<$ LOD & $<$ LOD & $<$ LOD & $<\mathrm{LOD}$ \\
\hline $\mathrm{Pb}, \mu \mathrm{g} \mathrm{L}^{-1}$ & $5.6 \pm 1.6$ & $0.8 \pm 0.3$ & $<$ LOD & $<$ LOD & $<$ LOD & $<$ LOD & $<$ LOD & $<$ LOD & $<\mathrm{LOD}$ \\
\hline \multicolumn{10}{|c|}{ From sand filter, large side-loop } \\
\hline $\mathrm{Al}, \mu \mathrm{g} \mathrm{L}^{-1}$ & $6900 \pm 4100$ & $92 \pm 16$ & $4.2 \pm 2.6$ & $<$ LOD & $<\mathrm{LOD}$ & $<$ LOD & $<\mathrm{LOD}$ & $<$ LOD & $<\mathrm{LOD}$ \\
\hline $\mathrm{Cd}, \mu \mathrm{g} \mathrm{L}^{-1}$ & $0.10 \pm 0.06$ & $0.14 \pm 0.01$ & $0.01 \pm 0.01$ & $<$ LOD & $<\mathrm{LOD}$ & $<$ LOD & $<\mathrm{LOD}$ & $<$ LOD & $<\mathrm{LOD}$ \\
\hline Co, $\mu \mathrm{g} \mathrm{L}^{-1}$ & $9.3 \pm 6.7$ & $0.8 \pm 0.1$ & $0.1 \pm 0.06$ & $0.9 \pm 0.1$ & $1.3 \pm 0.4$ & $<$ LOD & $1.3 \pm 0.9$ & $2.7 \pm 1.4$ & $2.3 \pm 0.6$ \\
\hline $\mathrm{Cu}, \mu \mathrm{g} \mathrm{L}^{-1}$ & $24 \pm 1.6$ & $35 \pm 5.0$ & $5.2 \pm 0.6$ & $27 \pm 2.4$ & $31 \pm 14$ & $21 \pm 4.8$ & $27 \pm 3.6$ & $24 \pm 12$ & $12 \pm 2.0$ \\
\hline $\mathrm{Mn}, \mu \mathrm{g} \mathrm{L}^{-1}$ & $670 \pm 14$ & $40 \pm 10$ & $4.8 \pm 4.4$ & $19 \pm 1.4$ & $7.0 \pm 0.8$ & $180 \pm 22$ & $240 \pm 2.2$ & $290 \pm 71$ & $390 \pm 14$ \\
\hline $\mathrm{Ni}, \mu \mathrm{g} \mathrm{L}^{-1}$ & $7.9 \pm 2.8$ & $4.5 \pm 0.7$ & $0.7 \pm 0.1$ & $<$ LOD & $<\mathrm{LOD}$ & $<$ LOD & $1.2 \pm 0.9$ & $0.8 \pm 1.0$ & $<\mathrm{LOD}$ \\
\hline $\mathrm{Pb}, \mu \mathrm{g} \mathrm{L}^{-1}$ & $14 \pm 12$ & $0.9 \pm 0.2$ & $<\mathrm{LOD}$ & $<$ LOD & $<\mathrm{LOD}$ & $<\mathrm{LOD}$ & $<\mathrm{LOD}$ & $<$ LOD & $<$ LOD \\
\hline
\end{tabular}

${ }^{*} L O D$ Level of detection

The highest concentrations were found after the startup of the experiment (Fig. 4), resulting 0.6-2.0 mg L after the woodchip bioreactor and $0.7-1.65 \mathrm{mg} \mathrm{L}^{-1}$ after the sand filter a few days later. It can be assumed that the fatty acids were first released from the birch woodchips into the circulating water. After 1 week of experiment, the levels of each fatty acid settled at below $0.5 \mathrm{mg} \mathrm{L}^{-1}$ throughout the rest of the experiment. Additionally, the concentrations were moderately higher in systems with the large side-loop compared to those with the small side-loop.

Fatty acids have a long carbon chain, giving them their lipophilic and hydrophobic nature. Due to their hydrophobicity, they do not seek into the circulating water, and only low concentrations of fatty acids originating from birch wood were accumulated into the system.

Octanoic acid has biocidal properties, hexanoic acid both biocidal and plant protection properties, while benzoic acid is known to have biocidal properties but also corrosive and hazardous effects to health (ECHA 2019). A low EC50 value $\left(9 \mathrm{mg} \mathrm{L}^{-1}\right)$ for benzoic acid has been reported in a chronic study with cyanobacterium Anabaena inaequalis, while for the freshwater fish golden ide Leuciscus idus, a 48-h LC50 of $460 \mathrm{mg} \mathrm{L}^{-1}$ has been determined (WHO 2000). Compared to the known toxicity levels, the concentrations of this study remain below the limit values. 
Table 5 Concentrations $\left(\mu \mathrm{g} \mathrm{L}^{-1}\right)$ of acute or chronic toxicity, or limits for optimum water quality for aquatic life

$\mathrm{Ca}, \mu \mathrm{g} \mathrm{L} \mathrm{L}^{-1} \quad 4-160$

Cd, $\mu \mathrm{g} \mathrm{L}{ }^{-1} \quad$ Acute 1.8 ; chronic 0.72 acute 33; chronic 7.9

$\mathrm{Cu}, \mu \mathrm{g} \mathrm{L}{ }^{-1} \quad$ Acute 4.8 ; chronic $3.150-130$

$\mathrm{Fe}, \mu \mathrm{g} \mathrm{L}^{-1}>0-150,500$

$\mathrm{Mn}, \mu \mathrm{g} \mathrm{L} \mathrm{L}^{-1}>0-10$

$\mathrm{Ni}, \mu \mathrm{g} \mathrm{L}{ }^{-1} \quad$ acute 470 ; chronic 52 acute 74 ; chronic 8.2

$\mathrm{P}, \mu \mathrm{g} \mathrm{L}^{-1} \quad 10-3000$

$\mathrm{Pb}, \mu \mathrm{g} \mathrm{L}^{-1} \quad>0-30$ acute 82 ; chronic 3.2 acute 140 ; chronic 5.6
Hatchery water, trout

In fresh water

In salt water

In salt water $96 \mathrm{~h}$ LC50 for rainbow trout

Total, hatchery water, trout Ferric ion

Hatchery water, trout

In fresh water

In salt water

Hatchery water, trout

For salmonids

In fresh water

In salt water
Piper et al. 1986

US EPA (2019)*

US EPA (2019)* Gündoğdu 2008

Piper et al. 1986

Piper et al. 1986

US EPA (2019)*

Piper et al. 1986

Piper et al. 1986 US EPA (2019)*

* $100 \mathrm{mg} \mathrm{L}^{-1}$ water hardness as $\mathrm{CaCO}_{3}$

\section{Elemental analysis}

Results of elemental analyses of trace elements have been listed in Table 4. According to EU's drinking water standard (Council Directive 98/83/EC 1998), limit values have been set for a variety of compounds and elements, while US EPA (2019) has published limit values of certain heavy metals and toxic compounds for aquatic life. It can be used as a reference when evaluating the concentrations found in
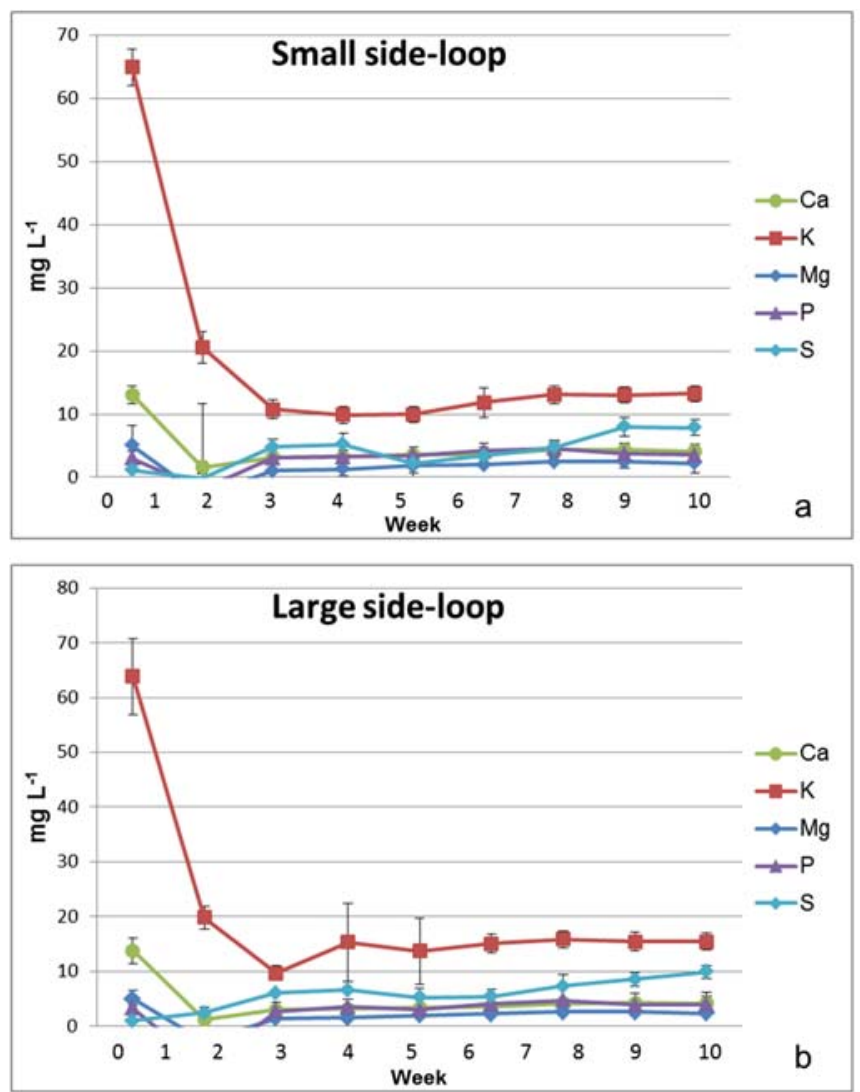

Fig. 5 Concentrations of calcium $(\mathrm{Ca})$, potassium $(\mathrm{K})$, magnesium $(\mathrm{Mg})$, phosphorous (P), and sulfur (S) $\left(\mathrm{mg} \mathrm{L}^{-1} \pm \mathrm{SD}, n=4\right)$ in circulating water after the woodchip bioreactor (a small side-loop, b large side-loop) and the circulating water. Especially, the concentrations of lead $(\mathrm{Pb})$ remain below $1 \mu \mathrm{g} \mathrm{L}^{-1}$ (limit value $10 \mu \mathrm{g} \mathrm{L}^{-1}$ ) for the first 2 weeks of the experiment and then decrease below LOD. In the case of $\mathrm{Cd}$, values were first below $1 \mu \mathrm{g} \mathrm{L}^{-1}$ (limit value $5 \mu \mathrm{g} \mathrm{L}^{-1}$ ), decreasing to below LOD. Overall, the levels detected in this study were generally well below the limit values, even at the beginning of the experiment. Additionally, the system settles at a low level rapidly after the start-up. This suggests that these trace elements do not
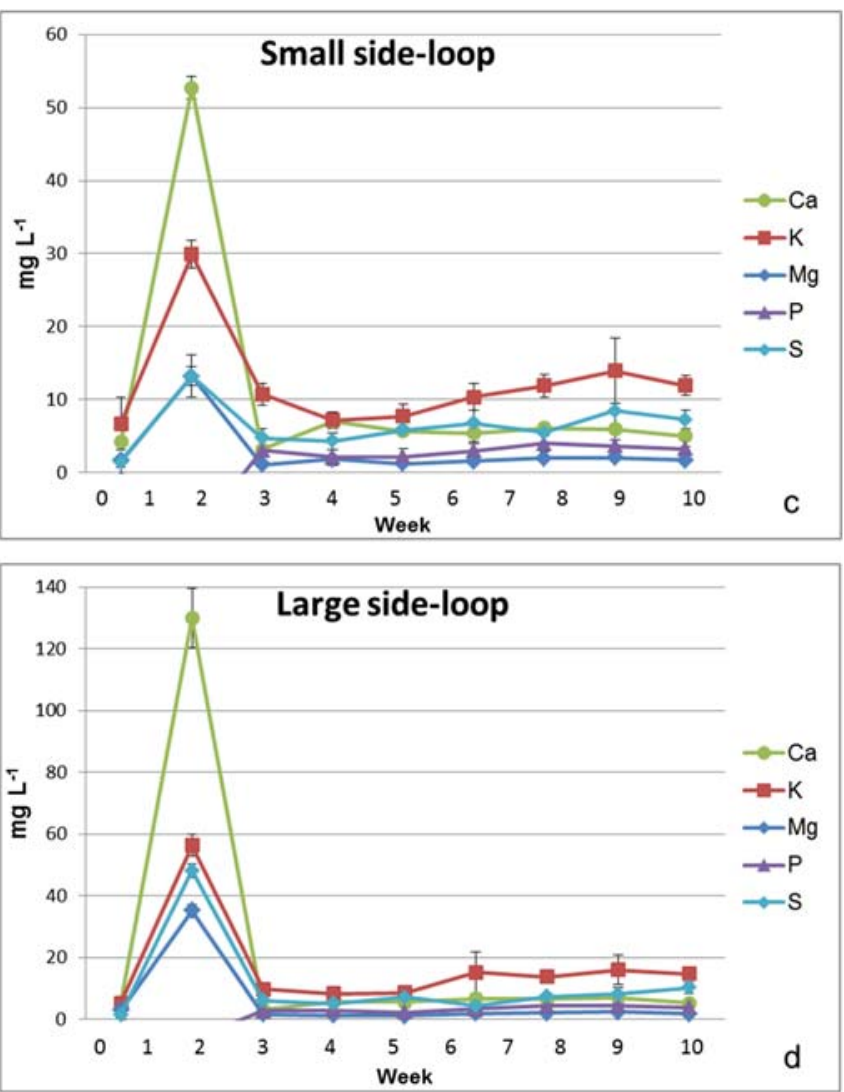

after the sand filter (c small side-loop, d large side-loop) during the 10 weeks of the experiment 
seem to accumulate into the system nor pose a risk towards the raised species. This is in agreement with the results of fatty acids (Fig. 4).

Compared to concentrations detected by Martins et al. (2011) in a RAS rearing Nile tilapia Oreochromis niloticus at similar water renewal rates, the concentrations were in the same range or lower. Only manganese was found at higher levels in this study. On the other hand, van Bussel et al. (2014) found manganese $422 \mu \mathrm{L}^{-1}$ at water renewal rate of $10 \mathrm{~L} \mathrm{~kg}^{-1}$ $\mathrm{d}^{-1}$ and $40 \mu \mathrm{g} \mathrm{L}^{-1}$ at $33 \mathrm{~L} \mathrm{~kg}^{-1} \mathrm{~d}^{-1}$ in a marine RAS rearing juvenile turbot Psetta maxima. Additionally, the concentrations remained below the limit values for chronic exposure for aquatic life $\left(\mathrm{Cd} 0.72 \mu \mathrm{g} \mathrm{L}^{-1}, \mathrm{Ni} 52 \mu \mathrm{g} \mathrm{L}^{-1}, \mathrm{~Pb}\right.$ $3.2 \mu \mathrm{g} \mathrm{L}^{-1}$ ) set by the US EPA (US EPA 2019, Table 5).

In the case of manganese, the concentrations ranged from 330 to $1100 \mathrm{mg} \mathrm{L}^{-1}$ in the beginning of the experiment. After the start-up of the system, concentrations decreased even to a few $\mu \mathrm{g} \mathrm{L}^{-1}$ of manganese in some cases (Table 4) but increased again to 55-390 $\mathrm{g} \mathrm{L}^{-1}$ range in the end of the experiment. Manganese is typically of geological origin and one of the most common heavy metals in soil. In Finland, the average levels of manganese (285 $\mathrm{mg} \mathrm{kg}^{-1}$, Rasilainen et al. 2007) are lower than on average in the earth crust (630 $\mathrm{mg} \mathrm{kg}^{-1}$, Kousa et al. 2017). In this study, the sand was collected locally from the area where soil is known to contain manganese. Precipitation of manganese proceeds at $\mathrm{pH}$ range $4-7$, but it is also affected by the bicarbonate and sulfate concentrations (Kousa et al. 2017). However, the dependence between $\mathrm{pH}$ and the amount of release manganese has not been fully resolved (Kousa et al. 2017). An upper limit of $10 \mu \mathrm{g} \mathrm{L}^{-1}$ has been set for optimum trout hatchery water (Piper et al. 1986), but according to our knowledge, limit values for optimum circulating water has not been set.

In the latter part of the experiment, concentrations of manganese increased, as well as those of sulfate (Table 4, Fig. 3c), which may have promoted the release of manganese from the sand filter. Concentration of manganese found in the inlet water from Lake Peurunka was only $6.2 \pm 3.3 \mu \mathrm{g} \mathrm{L}{ }^{-1}$, which cannot explain the increased values after the sand filter. This suggests that process conditions of the system have a more substantial effect on the manganese content in the circulating water than its content in the sand filter sand or in the inlet water.

At the beginning of the experiment, increased concentrations up to $70 \mathrm{mg} \mathrm{L}^{-1}(\mathrm{~K})$ of selected elements were detected (Fig. 5a, b) after the woodchip bioreactor and up to $130 \mathrm{mg} \mathrm{L}^{-1}(\mathrm{~K})$ after the sand filter (Fig. 5c, d) after 1 week of the experiment. As in the case of most trace elements (Table 4), the concentrations decreased rapidly and remained below $20 \mathrm{mg} \mathrm{L}^{-1}$ throughout the rest of the experiment.
These elements can be of woodchip origin and thus originate from the woodchip bioreactor. For example, Werkelin et al. (2005) reported concentration ranges 700$900 \mathrm{mg} \mathrm{kg}^{-1}$ for $\mathrm{Ca}$, 500-600 $\mathrm{mg} \mathrm{kg}^{-1}$ for $\mathrm{K}, 110$ $160 \mathrm{mg} \mathrm{kg}^{-1}$ for $\mathrm{Mg}$, and $50-60 \mathrm{mg} \mathrm{kg}^{-1}$ for $\mathrm{P}$ in birch (Betula pubescens) stem wood, while bark can contain even higher levels (Ca 7100-5500 mg kg-1, 2100-2300 mg kg-1, P 460-300 mg kg-1, Werkelin et al. 2005). Other limit values for acute and chronic toxicity in water and limits for optimum water quality for aquatic life or for salmonids have been listed in Table 5 .

\section{Toxicity}

The circulation waters studied did not lead to inhibition of luminescent bacteria Vibrio fischeri during the acute exposure. Based on the results, the circulation water did not show inhibitive effects (Supplementary Table S7).

In the acute toxicity test for Daphnia longispina, $40 \%$ immobility occurred in the control water of the test control. For the circulating water, the rate of mortality (immobility) ranged widely from $0 \%$ to $100 \%$ but did not show a clear trend between the treatments (Supplementary Table S8). However, the rate of mortality (immobility) was lower in the inlet water $(4 \%)$ than in the circulating water, except in one of the systems with a small side-loop $(0 \%)$. The results suggest that circulating water can show toxic effects to some species, but the toxic effects do not seem to be caused by the units of the side-loops.

\section{Conclusions}

This study represents a new process design for circulating water treatment and denitrification in RAS by combining denitrification in a woodchip bioreactor and slow sand filtration. The results show that birch woodchips act as a carbon source and provide surface area for the denitrification. The levels of the anions studied remained at reasonable levels in the rearing tanks and in the side-loops for the first part of the experiment, unlikely causing discomfort or harm for the raised species. However, as the experiment proceeded, the denitrification decreased and nitrate levels increased, suggesting an imbalance of the system and insufficient dimensioning of the reactors. However, this was the first experiment applying the new process configuration of water treatment for RAS. This shows that an improved dimensioning is required to ensure proper function of the woodchip bioreactor and the sand filter. Overall, the concentrations of compounds observed in the system were low, and only in some cases 
increased concentrations of nitrate, sulfate, and manganese were found. This suggests the suitability of the process for water treatment in RAS, aiming at decreasing the water consumption and growing healthy fish.

This was the first trial of this process design, requiring further studies of the denitrification efficiency and process control in the long run. Additionally, the developed analytical methods to study heavy metals, fatty acids, and anions can be applied to other processes, including large-scale facilities. Later, it is of interest to ensure that $\mathrm{N}_{2} \mathrm{O}$ will not be released and to ensure a good efficiency of denitrification.

Acknowledgments Open access funding provided by Natural Resources Institute Finland (LUKE). Financial support provided by the European Maritime and Fisheries Fund is gratefully acknowledged. We are thankful to the personnel of Chemistry department at the University of Jyväskylä for kindly providing comprehensive advice for the experimental work.

Author contributions The experiment was planned by Vielma, Pulkkinen, and Lindholm-Lehto. Lindholm-Lehto planned and conducted the sample preparations, method development, and analyses. The manuscript was drafted by Lindholm-Lehto. Vielma, Pulkkinen, and Kiuru critically examined and revised the manuscript.

\section{Compliance with ethical standards}

Conflict of interest The authors declare that they have no conflict of interest.

Open Access This article is licensed under a Creative Commons Attribution 4.0 International License, which permits use, sharing, adaptation, distribution and reproduction in any medium or format, as long as you give appropriate credit to the original author(s) and the source, provide a link to the Creative Commons licence, and indicate if changes were made. The images or other third party material in this article are included in the article's Creative Commons licence, unless indicated otherwise in a credit line to the material. If material is not included in the article's Creative Commons licence and your intended use is not permitted by statutory regulation or exceeds the permitted use, you will need to obtain permission directly from the copyright holder. To view a copy of this licence, visit http://creativecommons.org/licenses/by/4.0/.

\section{References}

Aslan S, Cakici H (2007) Biological denitrification of drinking water in a slow sand filter. J Hazard Mater 148:253-258. https://doi.org/10. 1016/j.jhazmat.2007.02.012

Aslan S, Turkman A (2003) Biological denitrification of drinking water using various natural organic solid substrates. Water Sci Technol 48: 489-495 doi.org/10.2166/wst.2004.0898

Billiard SM, Querbach K, Hodson PV (1999) Toxicity of retene to early life stages of two freshwater fish species. Environ Toxicol Chem 18: 2070-2077. https://doi.org/10.1002/etc.5620180927

Cameron SC, Schipper LA (2010) Nitrate removal and hydraulic performance of carbon substrates for potential use in denitrification beds. Ecol Eng 36:1588-1595. https://doi.org/10.1016/j.ecoleng.2010.03. 010
Chen S, Summerfelt S, Losordo T, Malone R (2002) Recirculating systems effluents, and treatment. In: Tomasso J (ed) Aquaculture and the environment in the United States. US Aquaculture Society, Baton Rouge, pp 119-140

Christianson LE, Bhandari A, Helmers MJ (2012) A practice-oriented review of woodchip bioreactors for subsurface agricultural drainage. Appl Eng Agric 28:861-874. https://doi.org/10.13031/2013.42479

Colt J (2006) Water quality requirements for reuse systems. Aquac Eng 34:143-156. https://doi.org/10.1016/j.aquaeng.2005.08.011

Council Directive 98/83/EC (1998) The drinking water directive on the quality of water intended for human 565 consumption. Official Journal of the European Communities L330, 5.12.1998, pp 32-54

Dalsgaard J, Lund I, Thorarinsdottir R, Drengstig A, Arvonen K, Bovbjerg Pedersen P (2013) Farming different species in RAS in Nordic countries: current status and future perspectives. Aquac Eng 53:2-13. https://doi.org/10.1016/j.aquaeng.2012.11.008

Destandau E, Vial J, Jardy A, Hennion M-C, Bonnet D, Lancelin P (2005) Development and validation of a reversed-phase liquid chromatography method for the quantitative determination of carboxylic acids in industrial reaction mixtures. J Chromatogr A 1088:49-56. https:// doi.org/10.1016/j.chroma.2005.01.002

Dodds WK, Bouska WW, Eitzmann JL, Pilger TJ, Pitts KL, Riley AJ, Schloesser JT, Thornbrugh DJ (2009) Eutrophication of U. S. Freshwaters: analysis of potential economic damages. Environ Sci Technol 43:12-19. https://doi.org/10.1021/es801217q

ECHA European chemicals agency (2019). Seach for chemicals https:// echa.europa.eu/. Accessed 7 May 2019

Eding EH, Kamstra A, Verreth JAJ, Huisman EA, Klapwijk A (2006) Design and operation of nitrifying trickling filters in recirculating aquaculture: a review. Aquacult Eng 34:234-260. https://doi.org/10. 1016/j.aquaeng.2005.09.007

Fernández-Nava Y, Marañón E, Soons J, Castrillón L (2008) Denitrification of wastewater containing high nitrate and calcium concentrations. Bioresour Technol 99:7976-7981. https://doi.org/ 10.1016/j.biortech.2008.03.048

Garcia-Ac A, Segura PA, Viglino L, Fürtös A, Gagnon C, Prévost M, Sauvé S (2009) On-line solid-phase extraction of large-volume injections coupled to liquid chromatography-tandem mass spectrometry for the quantitation and confirmation of 14 selected trace organic contaminants in drinking and surface water. J Chromatogr A 1216:8518-8527. https://doi.org/10.1016/j.chroma.2009.10.015

Gibert O, Pomierny S, Rowe I, Kalin RM (2008) Selection of organic substrates as potential materials for use in a denitrification permeable reactive barrier (PRB). Bioresour Technol 99:7587-7596. https://doi.org/10.1016/j.biortech.2008.02.012

Greenan CM, Moorman TB, Kaspar TC, Parkin TB, Jaynes DB (2006) Comparing carbon substrates for denitrification of subsurface drainage water. J Environ Qual 35:824-829. https://doi.org/10.2134/ jeq2005.0247

Gündoğdu A (2008) Acute toxicity of zinc and copper for rainbow trout (Onchorhyncus mykiss). J FisheriesSciences.com 2: 711-721. doi: https://doi.org/10.3153/jfscom.2008039

Healy MG, Ibrahim TG, Lanigan GJ, Serrenho AJ, Fenton O (2012) Nitrate removal rate, efficiency and pollution swapping potential of different organic carbon media in laboratory denitrification reactors. Ecol Eng 40:198-209. https://doi.org/10.1016/j.ecoleng.2011. 12.010

Hoover NL, Bhandari A, Soupir ML, Moorman TB (2016) Woodchip denitrification bioreactors: impact of temperature and hydraulic retention time on nitrate removal. J Environ Qual 45:803-812. https:// doi.org/10.2134/jeq2015.03.0161

Kolehmainen RE, Tiirola M, Puhakka JA (2008) Spatial and temporal changes in actinobacterial dominance in experimental artificial groundwater recharge. Water Res 42:4525-4537. https://doi.org/ 
10.1016/j.watres.2008.07.039

Kousa A, Backman B, Komulainen H, Hartikainen S (2017) Kaivoveden mangaani, KAIMA-projekti (In Finnish). Geological Survey of Finland, Research report 95/2016

Leach J, Thakore A (1978) Compounds toxic to fish in pulp mill waste streams. Progr Water Technol 9:787-798

Lepine C, Christianson L, Davidson J, Summerfelt S (2018) Woodchip bioreactors as treatment for recirculating aquaculture systems' wastewater: a cost assessment of nitrogen removal. Aquacult Eng 83:85-92. https://doi.org/10.1016/j.aquaeng.2018.09.001

Lindroos A-J, Tamminen P, Heikkinen J, Ilvesniemi H (2016) Effect of clear-cutting and the amount of logging residues on chemical composition of percolation water in spruce stands on glaciofluvial sandy soils in southern Finland. Boreal Environ Res 21:134-148

Martins CIM, Eding EH, Verdegem MCJ, Heinsbroek LTN, Schneider O, Blancheton JP, Roque d'Orbcastel E, Verreth JAJ (2010) New developments in recirculating aquaculture systems in Europe: a perspective on environmental sustainability. Aquac Eng 43:83-93. https://doi.org/10.1016/j.aquaeng.2010.09.002

Martins CIM, Eding EH, Verreth JAJ (2011) The effect of recirculating aquaculture systems on the concentrations of heavy metals in culture water and tissues of Nile tilapia Oreochromis niloticus. Food Chem 126:1001-1005. https://doi.org/10.1016/j.foodchem.2010.11.108

Masser MP, Rackocy J, Losordo TM (1999) Recirculating aquaculture tank production systems: management of recirculating systems. Southern Regional Aquaculture Center, Publication no 452, 12 p

Oikari A, Lönn BE, Castrén M, Nakari T, Snickars-Nikinmaa B, Bister H, Virtanen E (1983) Toxicological effects of dehydroabietic acid (DHAA) on the trout, Salmo gairdneri Richardson, in fresh water. Water Res 17:81-89. https://doi.org/10.1016/0043-1354(83)90288-9

Oikari A, Fragoso N, Leppänen H, Chan T, Hodson PV (2002) Bioavailability to juvenile rainbow trout (Oncorhynchus mykiss) of retene and other mixed-function oxygenase-active compounds from sediments. Environ Toxicol Chem 21:121-128. https://doi.org/10. $1002 /$ etc. 5620210118

Peng G, Roberts JC (2000) Solubility and toxicity of resin acids. Water Res 34:2779-2785. https://doi.org/10.1016/S0043-1354(99)00406-6

Peters JH (1998) Artificial recharge of groundwater. Proceedings of the 3rd international symposium on artificial recharge of groundwaterTISAR '98. A.a. Balkema, Rotterdam, Bookfield

Piper RG, McElwain IB, Orme LE, McCraren JP, Fowler LG, Leonard JR (1986) Fish hatchery management. U.S. Dept. of the interior, fish and wildlife service, 517p. https://doi.org/10.5962/bhl.Title.4038

Pulkkinen JT, Kiuru T, Aalto SL, Koskela J, Vielma J (2018) Startup and effects of relative water renewal rate on water quality and growth of rainbow trout (Oncorhynchus mykiss) in a unique RAS research platform. Aquacult Eng 82:38-45. https://doi.org/10.1016/j. aquaeng.2018.06.003

Rasilainen K, Lahtinen R, Bornhorst T (2007) the rock geochemical database of Finland. Geological survey of Finland, research report 164, Espoo, Finland

Rivett MO, Buss SR, Morgan PP, Smith JWN, Bemment CD (2008) Nitrate attenuation in groundwater: a review of biogeochemical controlling processes. Water Res 42:4215-4232. https://doi.org/10. 1016/j.watres.2008.07.020

Robertson WD (2010) Nitrate removal rates in woodchip media of varying age. Ecol Eng 36:1581-1587. https://doi.org/10.1016/j.ecoleng. 2010.01.008

Robertson WD, Ford GI, Lombardo PS (2005) Wood-based filter for nitrate removal in septic systems. Trans ASAE 48:121-128. https://doi.org/10.13031/2013.17954

Saliling WJB, Westerman PW, Losordo TM (2007) Wood chips and wheat straw as alternative biofilter media for denitrification reactors treating aquaculture and other wastewaters with high nitrate concentrations. Aquacult Eng 37:222-233. https://doi.org/10.1016/j. aquaeng.2007.06.003

Schipper LA, Cameron S, Warneke S (2010a) Nitrate removal from three different effluents using large-scale denitrification. Ecol Eng 36: 1552-1557. https://doi.org/10.1016/j.ecoleng.2010.02.007

Schipper LA, Robertson WD, Gold AJ, Jaynes DB, Cameron SC (2010b) Denitrifying bioreactors - an approach for reducing nitrate loads to receiving waters. Ecol Eng 36:1532-1543. https://doi.org/10.1016/j. ecoleng.2010.04.008

Schuster C, Stelz H (1998) Reduction in the make-up water in semiclosed recirculating aquaculture systems. Aquacult Eng 17:167174. https://doi.org/10.1016/S0144-8609(98)00013-2

Seitzinger S, Harrison JA, Bohlke JK, Bouwman AF, Lowrance R, Peterson B, Tobias C, Van Drecht G (2006) Denitrification across landscapes and waterscapes: a synthesis. Ecol Appl 16:2064-2090. https://doi.org/10.1890/1051-0761(2006)016[2064:DALAWA]2.0. $\mathrm{CO} ; 2$

Sharrer KL, Christianson LE, Lepine C, Summerfelt ST (2016) Modeling and mitigation of denitrification 'woodchip' bioreactorphosphorus releases during treatment of aquaculture wastewater. Ecol Eng 93: 135-143. https://doi.org/10.1016/j.ecoleng.2016.05.019

Świetlik R, Trojanowska M, Rabek P (2012) Distribution patterns of cd, $\mathrm{cu}, \mathrm{Mn}, \mathrm{Pb}$ and $\mathrm{Zn}$ in wood fly ash emitted from domestic boilers. Chem Spec Bioavailab 25:63-70. https://doi.org/10.3184/ $095422912 X 13497968675047$

Tallec G, Garnier J, Billen G, Gousailles M (2008) Nitrous oxide emissions from denitrifying activated sludge of urban wastewater treatment plants, under anoxia and low oxygenation. Bioresour Technol 99:2200-2209. https://doi.org/10.1016/j.biortech.2007.05.025

Turcios AE, Papenbrock J (2014) Sustainable treatment of aquaculture effluents - what can we learn from the past for the future? Sustainability 6:836-856. https://doi.org/10.3390/su6020836

US EPA (2007) Method 3015a (SW-846): Microwave assisted acid digestion of aqueous samples and extracts. Revision 1. Washington, DC

US EPA (2019) National recommended water quality criteria - Aquatic life criteria table. https://www.epa.gov/wqc/national-recommendedwater-quality-criteria-aquatic-life-criteria-table. Accessed 10 December 2019

van Bussel CGJ, Schroeder JP, Mahlmann L, Schulz C (2014) Aquatic accumulation of dietary metals $(\mathrm{Fe}, \mathrm{Zn}, \mathrm{cu}, \mathrm{co}, \mathrm{Mn})$ in recirculating aquaculture systems (RAS) changes body composition but not performance and health of juvenile turbot (Psetta maxima). Aquacult Eng 61:35-42. https://doi.org/10.1016/j.aquaeng.2014.05.003

van Rijn J, Tal Y, Schreier HJ (2006) Denitrification in recirculating systems: theory and applications. Aquac Eng 34:364-376. https:// doi.org/10.1016/j.aquaeng.2005.04.004

von Ahnen M, Bovbjerg Pedersen P, Hoffmann CC, Dalsgaard J (2016) Optimizing nitrate removal in woodchip beds treating aquaculture effluents. Aquaculture 458:47-54. https://doi.org/10.1016/j. aquaculture.2016.02.029

von Ahnen M, Bovbjerg Pedersen P, Dalsgaard J (2018) Performance of full-scale woodchip bioreactors treating effluents from commercial RAS. Aquacult Eng 83:130-137. https://doi.org/10.1016/j.aquaeng. 2018.10.004

von Ahnen M, Aalto SL, Suurnäkki S, Tiirola M, Bovbjerg Pedersen P (2019) Salinity affects nitrate removal and microbial composition of denitrifying woodchip bioreactors treating recirculating aquaculture system effluents. Aquaculture 504:182-189. https://doi.org/10. 1016/j.aquaculture.2019.01.068

Warneke S, Schipper LA, Matiasek MG, Scow KM, Cameron S, Bruesewitz DA, McDonald IR (2011) Nitrate removal, communities 
of denitrifiers and adverse effects in different carbon substrates for use in denitrification beds. Water Res 45:5463-5475. https://doi.org/ 10.1016/j.watres.2011.08.007

Werkelin J, Skrifvars B-J, Hupa M (2005) Ash-forming elements in four Scandinavian wood species. Part 1: summer harvest. Biomass Bioenergy 29:451-466. https://doi.org/10.1016/j.biombioe.2005. 06.005

WHO, World Health Organization (2000) Benzoic acid and sodium benzoate. Concise International Chemical Assessment Document 26, Geneva
Wu Y, Clarke N, Mulder N (2010) Dissolved organic carbon concentrations in throughfall and soil waters at level II monitoring plots in Norway: short- and long-term variations. Water Air Soil Pollut 205: 273-288. https://doi.org/10.1007/s11270-009-0073-1

Publisher's note Springer Nature remains neutral with regard to jurisdictional claims in published maps and institutional affiliations. 